\title{
Some Sensitivity Analyses of an Hourly Soil-Plant Water Relations Model
}

\author{
R. J. Luxmoore \\ Janice L. Stolzy \\ J. T. Holdeman
}

\section{MSTER}

\section{OAK RIDGE NATIONAL LABORATORY}

OPERATED BY UNION CARBIDE CORPORATION FOR THE ENERGY RESEARCH AND DEVELOPMENT ADMINISTRATION 


\section{DISCLAIMER}

This report was prepared as an account of work sponsored by an agency of the United States Government. Neither the United States Government nor any agency Thereof, nor any of their employees, makes any warranty, express or implied, or assumes any legal liability or responsibility for the accuracy, completeness, or usefulness of any information, apparatus, product, or process disclosed, or represents that its use would not infringe privately owned rights. Reference herein to any specific commercial product, process, or service by trade name, trademark, manufacturer, or otherwise does not necessarily constitute or imply its endorsement, recommendation, or favoring by the United States Government or any agency thereof. The views and opinions of authors expressed herein do not necessarily state or reflect those of the United States Government or any agency thereof. 


\section{DISCLAIMER}

Portions of this document may be illegible in electronic image products. Images are produced from the best available original document. 
Printed in the United States of America. Available from National Technical Information Service

U.S. Department of Commerce

5285 Port Royal Road, Springfield, Virginia 22161

Price: Printed Copy $\$ 5.00$; Microfiche $\$ 2.25$

This report was prepared as an account of work sponsored by the United States Government. Neither the United States nor the Energy Research and Development Administration/United States Nuclear Regulatory Commission, nor any of their employees, nor any of their contractors, subcontractors, or their employees, makes any warranty, express or implied, or assumes any legal liability or responsibility for the accuracy, completeness or usefulness of any information, apparatus, product or process disclosed, or represents that its use would not infringe privately owned rights. 
Contract No. W-7405-eng-26

SOME SENSITIVITY ANALYSES OF AN HOURLY SOIL-PLANT

WATER RELATIONS MODEL

R. J. Luxmoore

Environmental Sciences Division

Janice L. Stolzy ${ }^{1}$

J. T. Holdeman

Computer Sciences Division

-

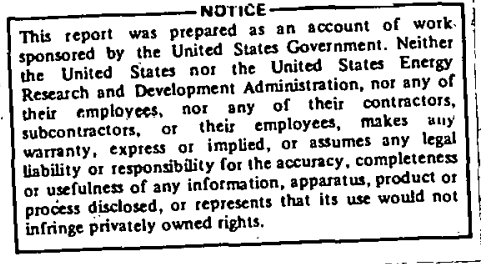

Environmental Sciences Division Publication No. 847

MAY 1976

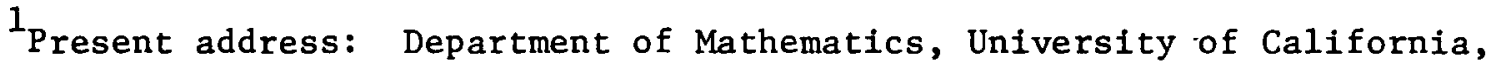
Riverside, California 92507.

\author{
, \\ OAK RIDGE NATIONAL LABORATORY \\ Oak R1dge, Tennessee 37830 \\ operated by \\ UNION CARBIDE CORPORATION \\ for the \\ ENERGY RESE $\Lambda$ RCH $\Lambda$ ND DEVELOPMENT $\Lambda$ DMINISTRATION
}




\section{THIS PAGE}

\section{WAS INTENTIONALLY \\ LEFT BLANK}


ABSTRACT

LUXMOORE, R. J., Janice L. STOLZY, and J. T. HOLDEMAN. 1976. Some sensitivity analyses of an hourly soil-plant water relations mode1. ORNL/TM-5343. Oak Ridge National Laboratory, Oak Ridge, Tennessee. $59 \mathrm{pp}$.

Nineteen parameters representing landscape, plant, and soil characteristics were examined for their influence on midday plant water relations; daily fluxes and month1y water balance components predicted by a soil-plant-water relations model having hourly resolution. A standard set of parameters was chosen to represent a hardwood forest on ridge top soil in the Oak Ridge, Tennessee area during a representative July (summer) month. Each parameter was varied through a range with all other parameters held at the standard value. The results of the study showed that the model was sensitive to nine plant parameters in noon, daily and monthly results. The ten other parameters had partial or no influence on the simulations. Two leaf characteristics and two landscape properties cause the model to be sensitive in midday values but less sensitive in monthly results due to the negative feedback aspects of the model. Five parameters had almost no influence on the model results in the case examined. The canopy interception parameter had almost no influence on the model results on sunny days, but was a significant component of the monthly water balance. The study highlighted the importance of the root and stem resistances to water flow in influencing plant water status and the monthly water balance.

This study has provided an assessment of the model stability to wide ranges of parameter values and suggests the model's utility in a 
range of applications. These would include forest and agricultural

crops on most soils and in diverse landscape situations. Further, the consequences of using parameters with high uncertainty in an application may be partially evaluated from these sensitivity tests. 
TABLE OF CONTENTS

Page

$\begin{array}{ll}\text { ABSTRACT } & \text { iii }\end{array}$

INTRODUCTION

METHODS 2

RESULTS 7

July Water Balance 7

$\begin{array}{ll}\text { Slope and Canopy Parameters } & 7\end{array}$

$\begin{array}{ll}\text { Leaf Parameters } & 12\end{array}$

$\begin{array}{ll}\text { Stem, Litter and Root Parameters } & 16\end{array}$

$\begin{array}{ll}\text { Root Conductivity and Soil Parameters } & 21\end{array}$

Water Status of Vegetation, Daily Evapotranspiration $\begin{array}{ll}\text { and Drainage } & 24\end{array}$

Slope and Canopy Parameters 24

Leaf Parameters $\quad 29$

Stem, Lit.ter and Root Parameters 35

$\begin{array}{ll}\text { Root Conductivity and Soil Parameters } & 40\end{array}$

DISCUSSION

REFERENCES

$\triangle{ }_{\triangle P P E N D I X} \quad-55$ 
THIS PAGE

WAS INTENTIONALLY

LEFT BLANK 
1. List of parameters and values used in sensitivity analyses.

2a. Sensitivity of midday surface water potential to slope and canopy parameters for six sunny days in July.

$2 b$. Sensitivity of midday surface conductance to slope and canopy parameters for six sunny days in July.

2c. Sensitivity of daily evapotranspiration rate to slope and canopy parameters for six sunny days in July:

2d. Sensitivity of daily drainage rate to slope and canopy parameters for six sunny days in July.

3a. Sensitivity of midday surface water potential to leaf parameters for six sunny days in July.

3b. Sensitivity of midday surface conductance to leaf parameters for six sunny days in July.

3c. Sensitivity of daily evapotranspiration rate to leaf parameters for six sunny days in July.

3d. Sensitivity of daily drainage rate to leaf parameters for six sunny days in July.

4a. Sensitivity of midday surface water potential to stem, litter and root parameters for six sunny days in July.

4b. Sensitivity of midday surface conductance to stem, litter and root parameters for six sunny days in July.

4c. Sensitivity of dally evapuliduspiration rate to otem, litter and root parameters for six sunny days in July.

4d. Sensitivity of daily drainage rate to stem, litter and root parameters for six sunny days in July.

5a. Sensitivity of midday surface water potential to root conductivity, soil hỹdraullc conductivity factor and soil layer parameters for six sunny days in July.

5b. Sensitivity of midday surface conductance to root conductivity, soil hydraulic conductivity factor and soil layer parameters for six sunny days in July. 
5c. Sensitivity of daily evapotranspiration rate to root conductivity, soil hydraulic conductivity factor and soil layer parameters for six sunny days in July.

5d. Sensitivity of daily drainage rate to root conductivity, soil hydraulic conductivity factor and soil layer parameters for six sunny days in July.

6. Subjective arrangement of parameters into four types based on the sensitivity of the monthly water balance, daily evapotranspiration rate and midday water relations to change in parameter value. 


\section{LIST OF FIGURES}

Page

1. Sensitivity of July water balance components to change in azimuth (AZIM) and inclination of land surface (INCL). summer albedo (ALBS).

3. Sensitivity of July water balance components to change in summer canopy wind coefficien't (SDRAG).

4. Sensitivity of July water balance components to change in summer canopy interception storage (EPXMAX).

5. Sensitivity of July water balance components to change in maximum leaf area index of the vegetation (ALMAX).

6. Sensitivity of July water balance components to change in the minimum resistance of the evapotranspiration surface (TMS).

7. Sensitivity of July water balance components to change in the maximum resistance of the evapotranspiration surface (RESS).

8. Sensitivity of July water balance components to change in the surface water potential at which surface resistance becomes maximum (PWPS).

9. Sensitivity of July water balance components to change in the exponential power term in the surface resistance equation (POWS).

10. Sensitivity of July water balance components to change in stem resistance (RSTEM).

11. Sensitivity of July water balance components to change in litter resistance (RLIT).

12. Sensitivity of July water balance components to change in the proportional distribution of roots (ARAT). (The extreme values of ARAT are 0.001 and 0.999 and not 0.0 and 1.0.)

13. Sensitivity of July water balance components to change in proportion of root cross sectional area in the first soil layer (AT (1)). 
14. Sensitivity of July water balance components to change in proportion of root cross sectional area in the second soll layer (AT (2)).

15. Sensitivity of July water balance components to change in root conductivity factor in the first soil layer (RTCON1).

16. Sensitivity of July water balance components to change in root conductivity factor in the second soil layer (RTCON2).

17. Sensitivity of July water balance components to change in saturated hydraulic conductivity factor (FACTOR).

18. Sensitivity of July water balance components to change in soil layer thickness (DL). 


\section{INTRODUCTION}

Sensitivity analyses of parameters in models provide information about the relative importance of parameters in determining the simulation results. On one hand, model output may not be affected by large changes in an input value. These insensitive parameters need not be determined with accuracy in the field for application with the given model. . Alternatively other parameters may have large effects on model, performance and should be accurately determined for the model application. Sensitivity analyses may also be helpful in gaining insights into the behavior of real world phenomena which have not been well characterized.

'There are several aspects of soil-plant-water flow that have a limited quantitative understanding although the basic physics and physiology of the system is qualitatively well known (Slatyer 1967, Kozlowski 1968). The Prosper model of atmosphere-soil-plant water flow (Goldstein and Mankin 1972) describes the basic flows and water status of vegetated land on a daily basis. This model has been made into an hourly version as part of the development of the Terrestrial Ecosystem Hydrology Mode1 (Huff et al. 1976).

The structural equations in Prosper represent a set of hypotheses and theories coupled in series and parallel and the results from any one simulation are determined by these hypotheses and theories. The formulation of the model is based on rather tenuous data in some of its aspects. For example, the resistance to water flow in the stem has a value of 5000 days in the daily Prosper model (Goldstein, Mankin and Luxmoore 1974). This value was obtained from Cowan's estimate of 
internal crop impedance to water flow (Cowan 1965). Prosper also has root conductivity terms that were defined as $10^{6}$ times the soil hydraulic conductivity in the two soil layers with roots. These values change each day with change in soil water content. Again little was known about root conductivity functions and an intuitive guess was used in the original model structure. The main purpose of these sensitivity analyses is to explore a physically and physiologically sensible range of parameter values to determine the effects predicted by the hourly Prosper model on the water budget of a forest. These tests will provide insights for the design of experiments to measure stem resistance, root conductivity or other components of this type of soil-plant water. continuum. Further, the study w111 provide a necessary assessment of the model performance and stability over a wide range of parameter values. The application of the model to a wide range of soil-plant systems may be attempted if the model exhibits reliable performance and stabllity in sensitivity tests. A standard set of parameters were chosen to represent the conditions of an oak forest on a forest soil during an average July month at Oak Ridge, Tennessee.

\section{METHODS}

The standard plant properties used in the model were similar to those reported by Goldstein and Mankin (1972) based on data obtained in eastern Tennessee from the Walker Branch watershed study and the Liriodendron forest study (Ecological Sciences Division Annual Progress Report 1971). The standard soil properties for Fullerton cherty siltloam were obtained from data reported by Peters et al. (1970). Their 
values of saturated hydraulic conductivity were exceedingly high and values about ten times less were chosen. These lower values gave matching factors (ratio between measured and calculated saturated hydraulic conductivity) obtained in the calculation of soil hydraulic properties (Luxmoore 1973) that were of the same order reported in other studies (e.g., Green and Corey 1971). The soil in the model applications was divided into five layers in all cases with the first layer having A horizon properties, the second layer B1 properties and the lower layers had B2 horizons characteristics.'A set of July meteorological data with characteristics close to the average were selected from NOAA records (ATDL 1972). July 1953 gave the closest agreement and these daily values were used in all the simulations (1isting in appendix). The model was run consecutively for three months with the same monthly meteorological data to eliminate the effects of initial values on the sensitivity tests. Preliminary tests showed that by the third month the major influences of initial conditions were eliminated. The results presented represent unconfounded effect of the parameter on the simulation output without confounding effects of initial conditions. The nineteen parameters listed in Table 1 were varied in the ranges indicated in the table (all other values held at the standard value). Interaction effects between parameters are not reported here. The following outline indicates the method by which the parameters enter into the model calculations. 
Table 1. Iist of parameters and values used in sensitivity analyses.

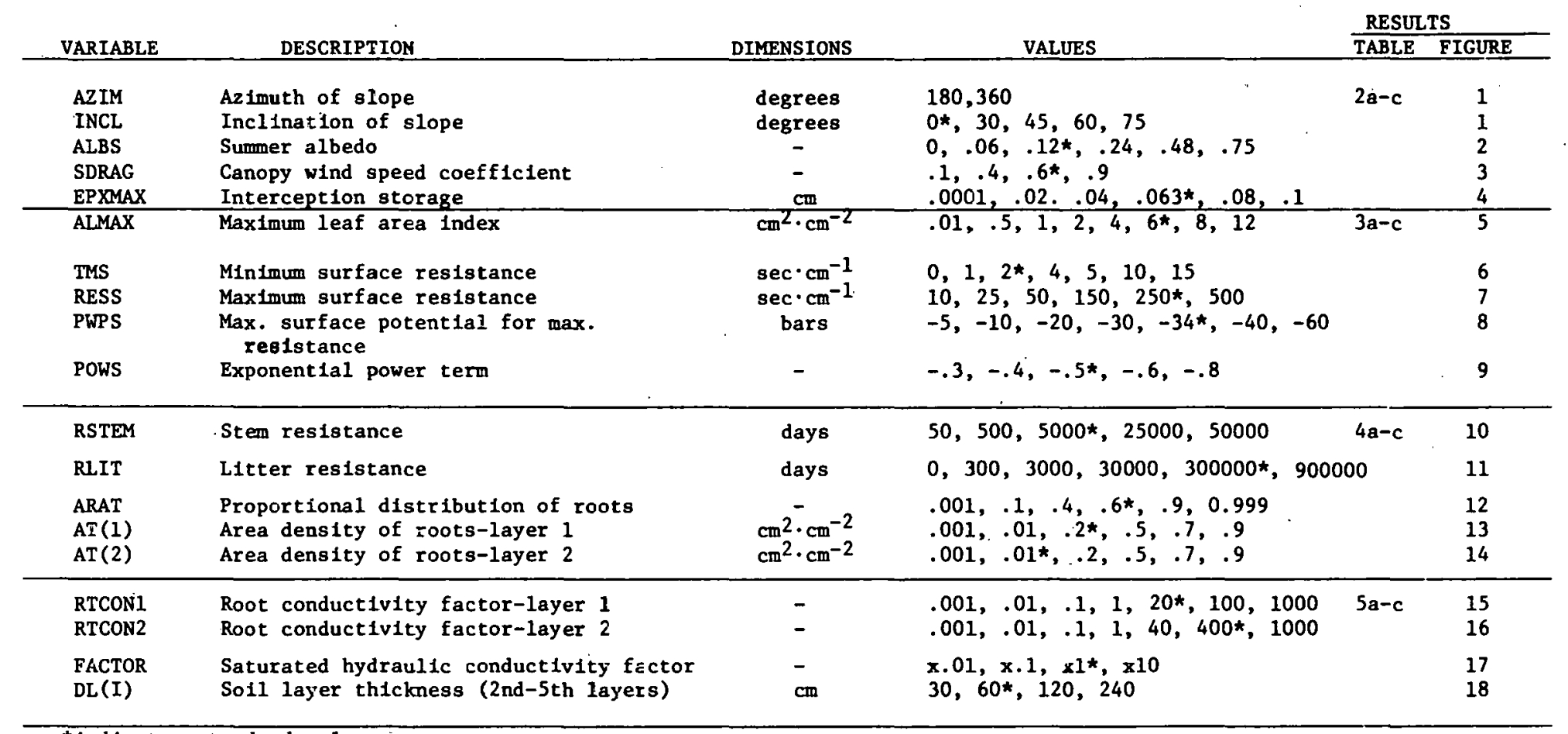

*indicates standard value.
xindicates multiplication. 
AZIM, INCL These are both used in subroutine ASPECT to determine an equivalent location on the earth's surface having the same exposure to the sun as the simulated slope. The methods of equivalent slope thenry are used to determine the daily radiation and daylength on the slope with the given zzimuth and inclination (Huff et al., 1976). Latitude of the slope is also used in these calculations, however this quantity was not varied in these sensitivity tests.

ALBS The albedo of the vegetation is used to determine the daily solar energy available (SOLAR) for evapotranspiration from the total incoming radiation $($ TOTSOL) $\cdot$ SOLAR $=$ TOTSOL $*(1 .-A L B S)$ SDRAG The wind drag coefficient determines the effective wind speed (EWIND) in the canopy from the above canopy wind speed (WIND) which is read in as input data. EWIND = WIND*SDRAG. EWIND is then used in empirical equations to determine the boundary layer diffusion resistance to heat and vapor flow. EPXMAX During rainfall (PREC), the summer interception storage by vegetation and litter must be filled from its current value (SCEP) to its maximum storage value (EPXMAX) before water infiltrates (FILT) into soil.

$$
\text { FILT }=\text { PREC }-(\text { EPXMAX-SCEP })
$$

ALMAX The leaf area index during the summer (ALMAX) enters into the calculations of the vapor loss from and liquid flow to the evapotranspiration surface. These involved computations are described in the appendix of Swift et al. (1975). 
TMS, RESS, PWPS, POWS These four terms determine the characteristics of the following empirical relationship between surface resistance (RX) and surface water potential (PWP), where EXP is the base of the natural logorithm. PWPS and PWP are in absolute values.

$$
\mathrm{RX}=\mathrm{TMS}+(\text { RESS-TMS }) * \operatorname{EXP}(\text { POWS } *(P W P S-P W P))
$$

TMS is the minimum surface resistance

RESS is the maximum surface resistance

PWPS is the water potential at which the surface resistance becomes maximum

POWS is the exponential power factor that determines the increase In $R X$ per unit of PWP

RSTEM, RLIT, ARAT, AT(1), AT(2), RTCON1, RTCON2 are a11 plant terms incorporated into the equations for liquid water flow solved by electrical network methods as outlined by Goldstein, Mankin and Luxmoore (1974).

SCON The standard saturated conductivity values (SCON) for the soil layers are multiplied by the values shown in Table 1 for the sensitivity tests. Each input value of saturated conductivity is used to obtain a matching factor that is applied to the range of calculated unsaturated hydraulic conductivity values to give scaled values appropriate for each application. Hydraulic conductivity determines the water flow rate between soil layers and the water flow rate to roots. These flows are included in the electrical network equations used to solve the liquid water flow to the leaf surface. 
DL The soil layer thickness enters into the water potential gradient component of soil water fluxes (FLOW)

$$
\text { FLOW }=\operatorname{COND} * \frac{(\mathrm{SP} \emptyset \mathrm{T}(1)-\operatorname{SPOT}(2)}{(\mathrm{DL}(1)+\mathrm{DL}(2)) / 2}
$$

where COND is the average soil hydraulic conductivity between the two soil layers and SPOT is the soil water potential.

\section{RESULTS}

July Water Balance

The mass balance equation for the month relates the inputs, outputs and changes of storage. In this study the equation is

$\begin{aligned} \text { INPUT }= & \begin{array}{l}\text { } \text { OUTPUTS } \\ \text { interception evaporation } \\ \text { transpiration }\end{array}=\begin{array}{l}\text { Interception } \\ \text { soil evaporation }+ \\ \text { drainage } \\ \text { runnff }\end{array}\end{aligned}$

Change in interception storage was zero in all cases since initially the value was zero and at the end of the month water in interception storage had completely evaporated. For purposes of comparison the mass balance equation was normalized by dividing each of the components by the monthly precipitation. These normalized values are presented in the figures which follow.

Slope and Canopy Parameters (Fig. 1, 2, 3, 4)

The comparison of north $($ AZIM $=360)$ and south $(A Z I M=180)$ facing slopes showed surprisingly little change in the components of the water balance for slope inclinations up to $75^{\circ}$ (Fig. 1). However, the differences in solar radiation received on sloping surfaces are at a minimum 
ORNL-DWG 75-14012

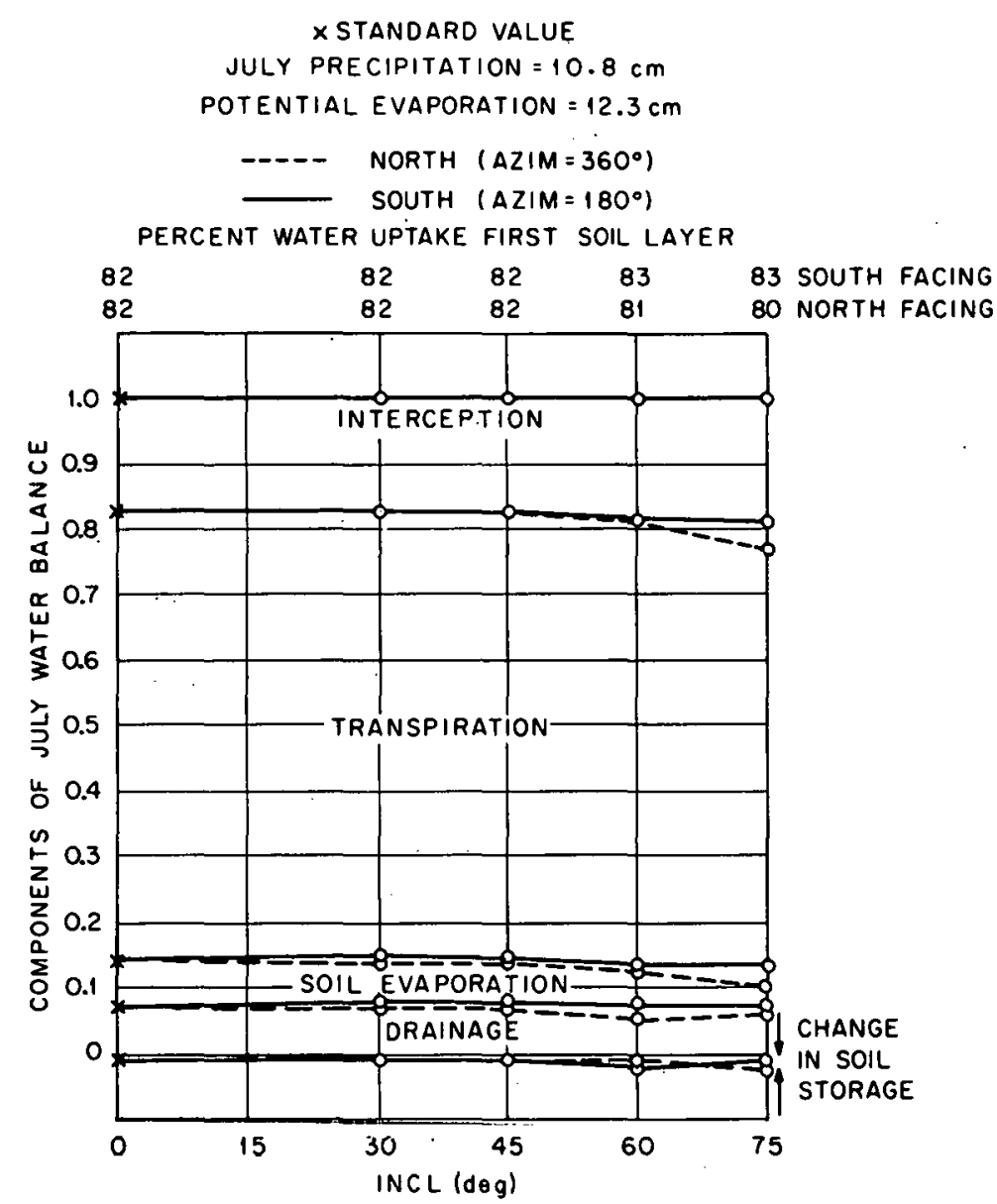

Fig. 1. Sensitivity of July water balance components to change in azimuth (AZIM) and inclination of land surface (INCL). 


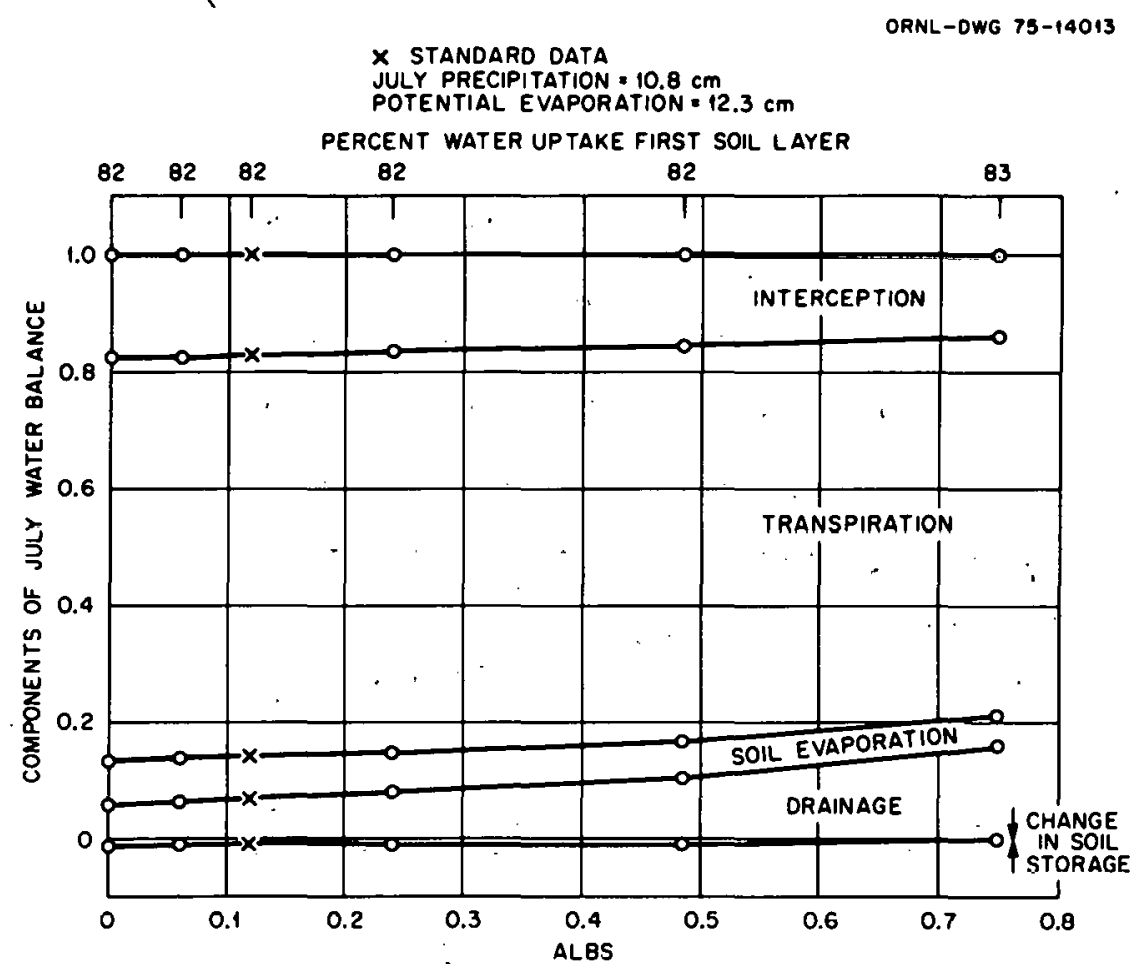

Fig. 2. Sensitivity of July water balance companents to change in summer albedo (ALBS).

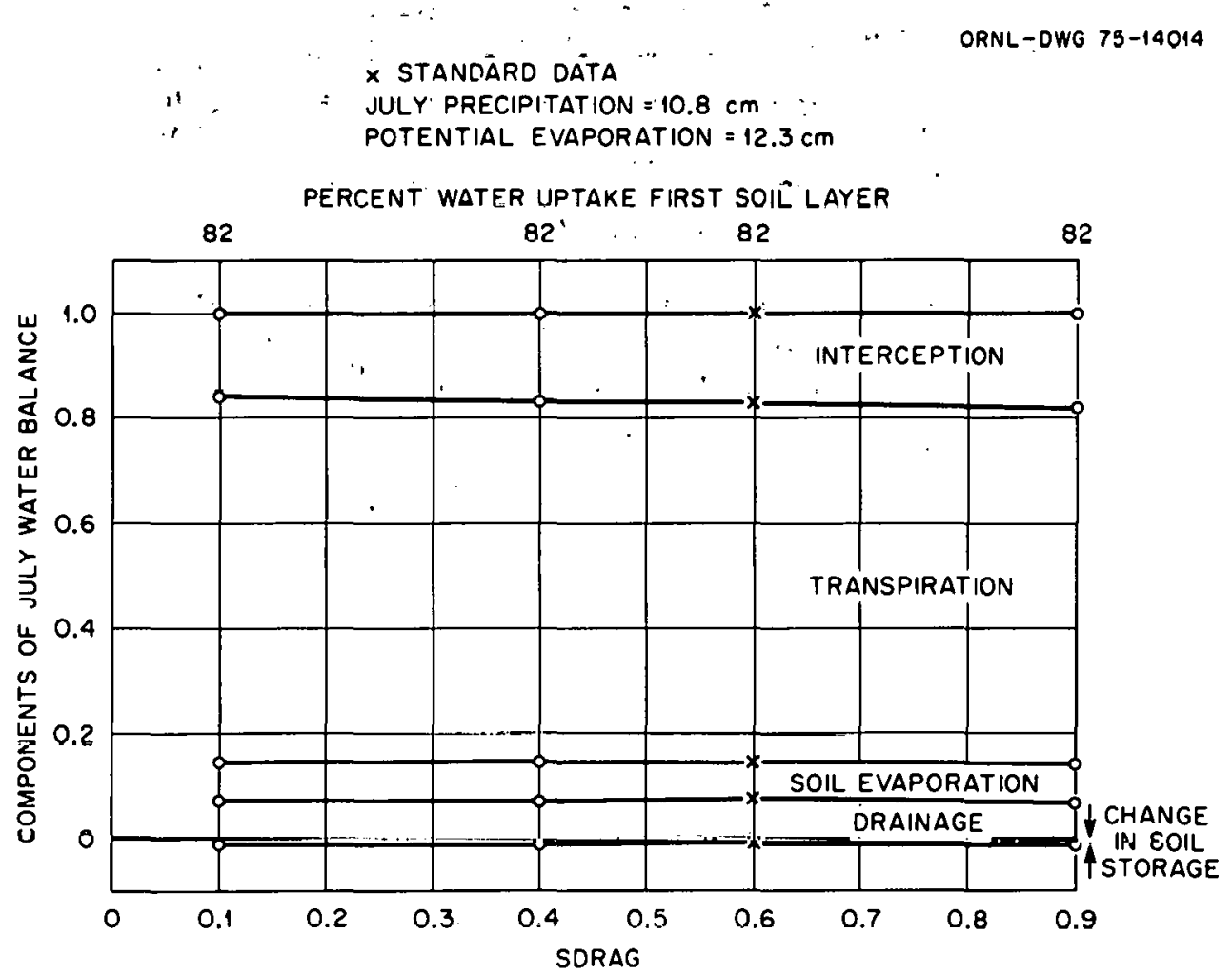

F1g. 3. Sensitivity of July water balance components to change in summer canopy wind coefficient (SDRAG). 


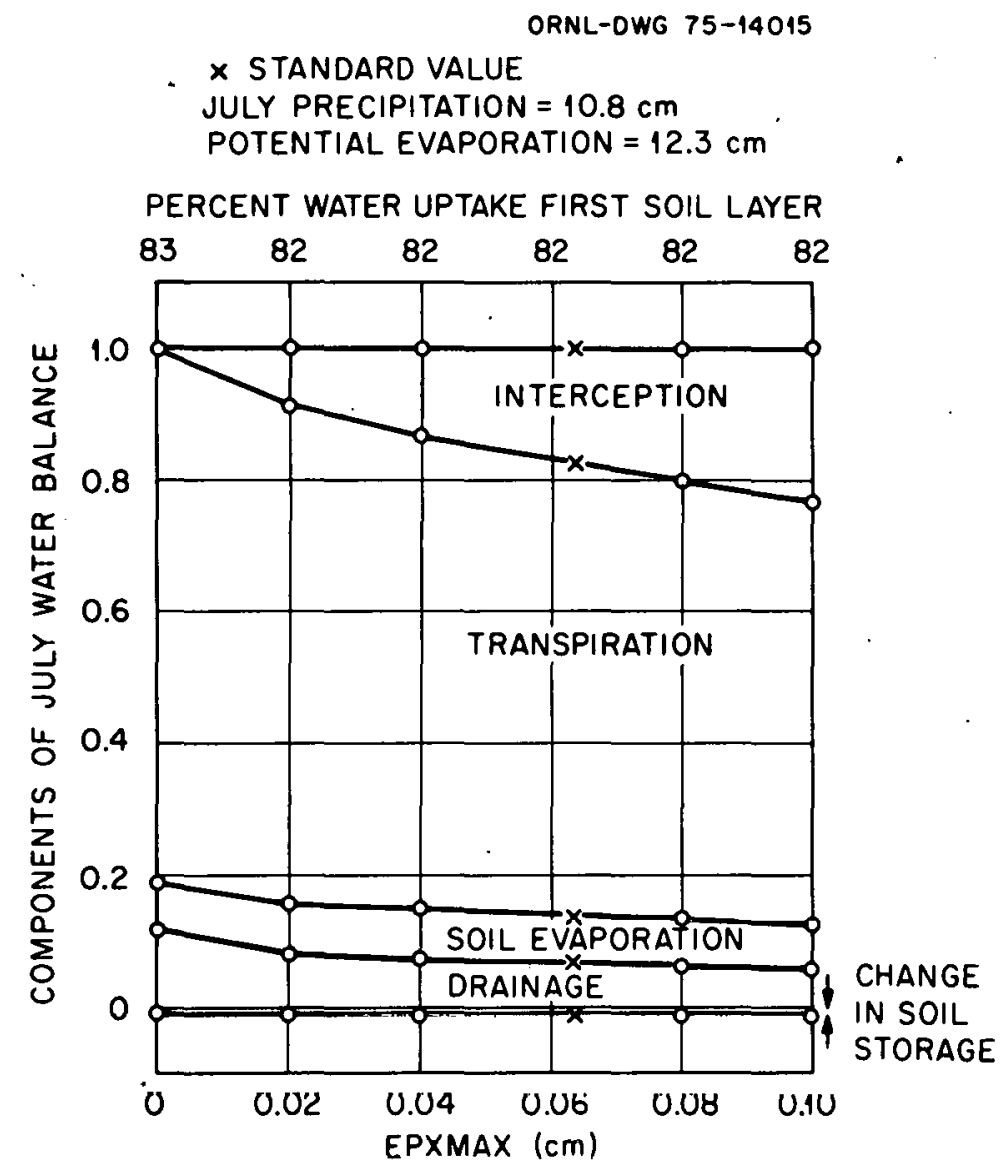

Fig. 4. Sensitivity of July water balance components to change in summer canopy interception storage (EPXMAN). 
during the summer period in the northern hemisphere. Also the model simulations are adjusted to a horizontal area basis. Thus a $75^{\circ}$ slope has a larger actual area with lower irradiance per unit area than a horizontal surface resulting in the total irradiance being similar for both surfaces. Larger differences would be expected during winter months: There was no significant effect of either azimuth or slope on the proportion of water taken up from the first soil layer, which was $82 \%$ for slopes less than $45^{\circ}$.

An increase in albedo (ALBS) of the canopy induced reductions in both interception evaporation and transpiration and an increase in drainage (Fig. 2). In the range of vegetation albedos from 0.05 to 0.25 , the model has a low sensitivity. Similarly, there were no effects on the distribution of root water uptake.

The wind speed given for a particular day is multiplied by SDRAG in the model to give the estimated wind speed in the canopy. There was a slight increase in interception evaporation and concomitant decrease in transpiration with increase in $\operatorname{SDRAG}$ (Fig. 3). Wind speed is used in an empirical equation to calculate boundary layer diffusion resistance. The resistance value in turn is used in the evapotranspiration (ET) equation. The model has a low sensitivity to wind speed.

Interception storage represents the combined thickness of surfaces that can be wetted by rain per unit soil area. It is composed of leaf, stem, twig, bark and litter surfaces. Initial tests showed that a value of $0.0635 \mathrm{~cm}$ thickness was needed to give good agreement with the Helvey and Patrick (1965) empirical equations. Interception increased 
with increase in EPXMAX and transpiration was reduced (Fig. 4). Drainage was higher at very low EPXMAX values. Some attempt to obtain realistic values for EPXMAX are necessary in any application of the model. In the standard run, interception was $17 \%$ of the July precipitation.

Leaf Parameters (Fig. 5, 6, 7,8,9)

The maximum leaf area index (ALMAX) had little effect on the water balance at values above $3.5 \mathrm{~cm}^{2} \cdot \mathrm{cm}^{-2}$ (Fig. 5). Decrease in leaf area index below 3 caused a marked decrease in transpiration and increase in drainage. Soil evaporation increased a small amount with decrease in leaf area. The formalization of the model was based on the assumption. of a uniform evapotranspiration surface (full canopy or litter) and the interpolation to leaf area indices between a full canopy and litter (LAI $\simeq 0.0$ ) may give poor simulaton results. Increase in leaf area index from low (.001) to high (12) values was accompanied with increase in the proportion of water taken up from the first soil layer (A horizon). This reflected the drying of the first layer and rewetting by rainfall with reduced water flux between soil layers as the amount of transpiration increased with increase in leaf area index.

Increase in minimum surface resistance (TMS) to vapor loss caused a decrease in both transpiration and soil evaporation and an increase in drainage (Fig. 6). Change in soil water storage showed little response to change in TMS. There was no effect on interception evaporation. Water uptake from the first soil layer increased with increase in TMS. 


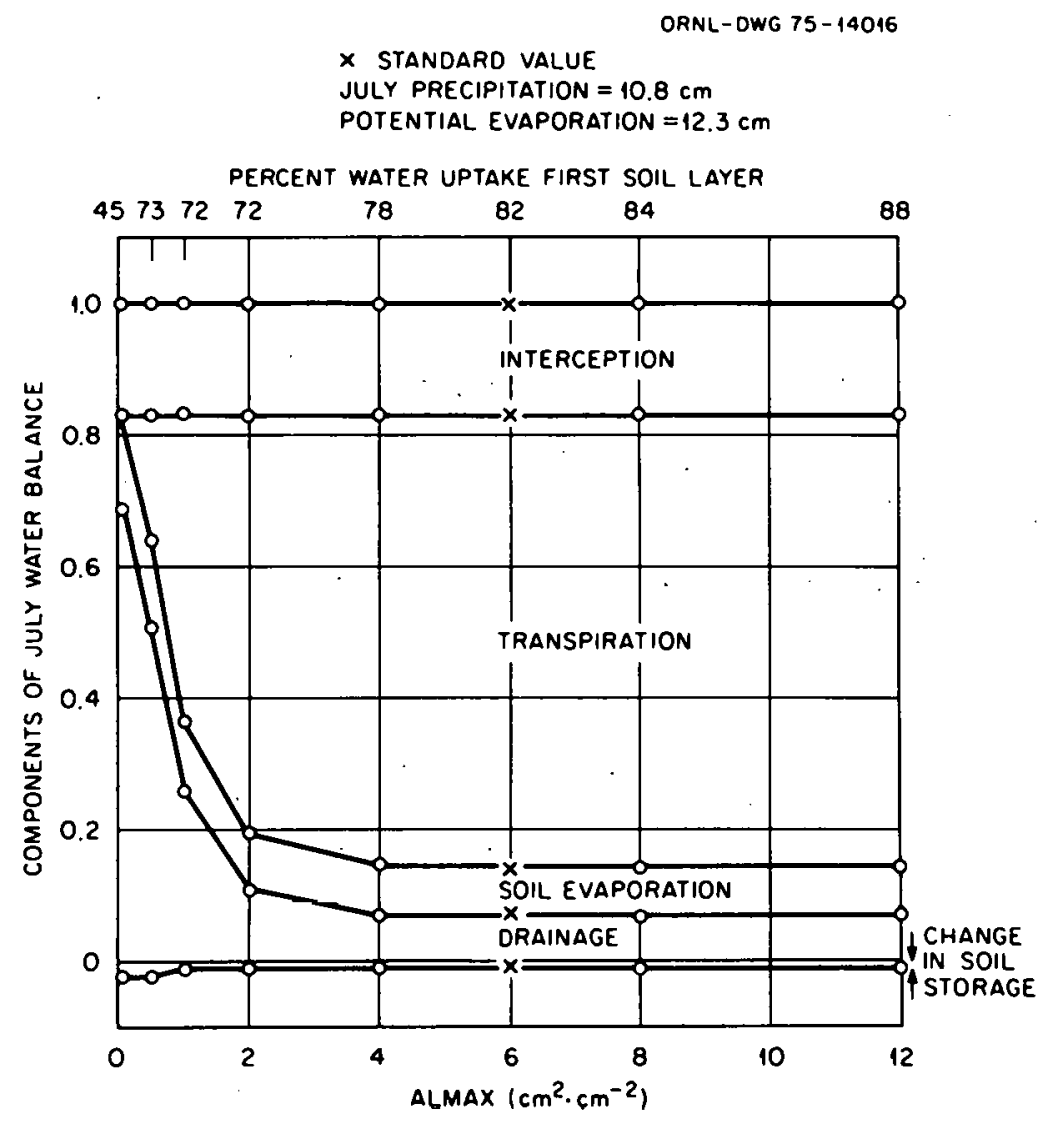

Fig. 5. Sensitivity of July water balance components to change in maximum leaf area index of the vegetation (ALMAX). 


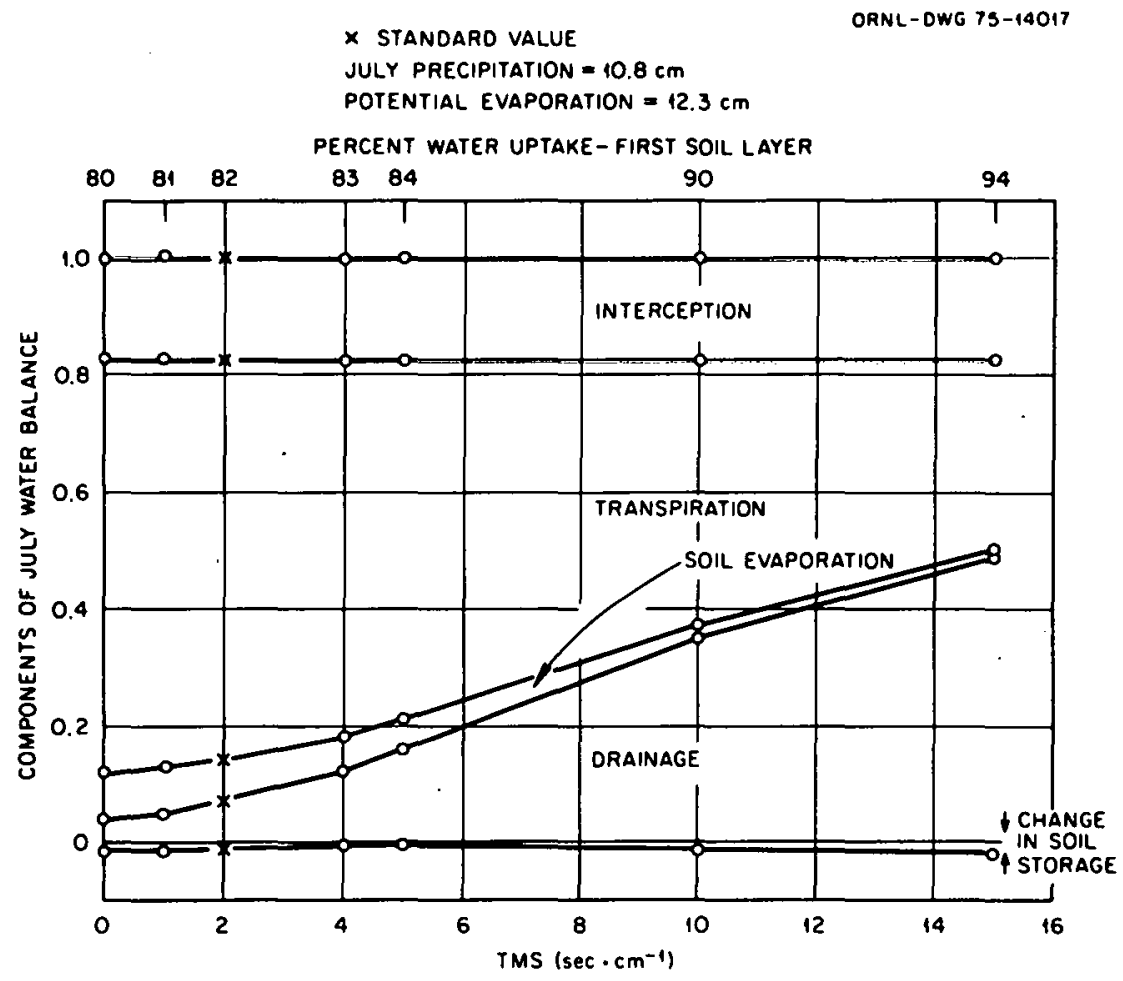

Fig. 6. Sensitivity of July water balance components to change in the minimum resistance of the evapotranspiration surface (TMS).

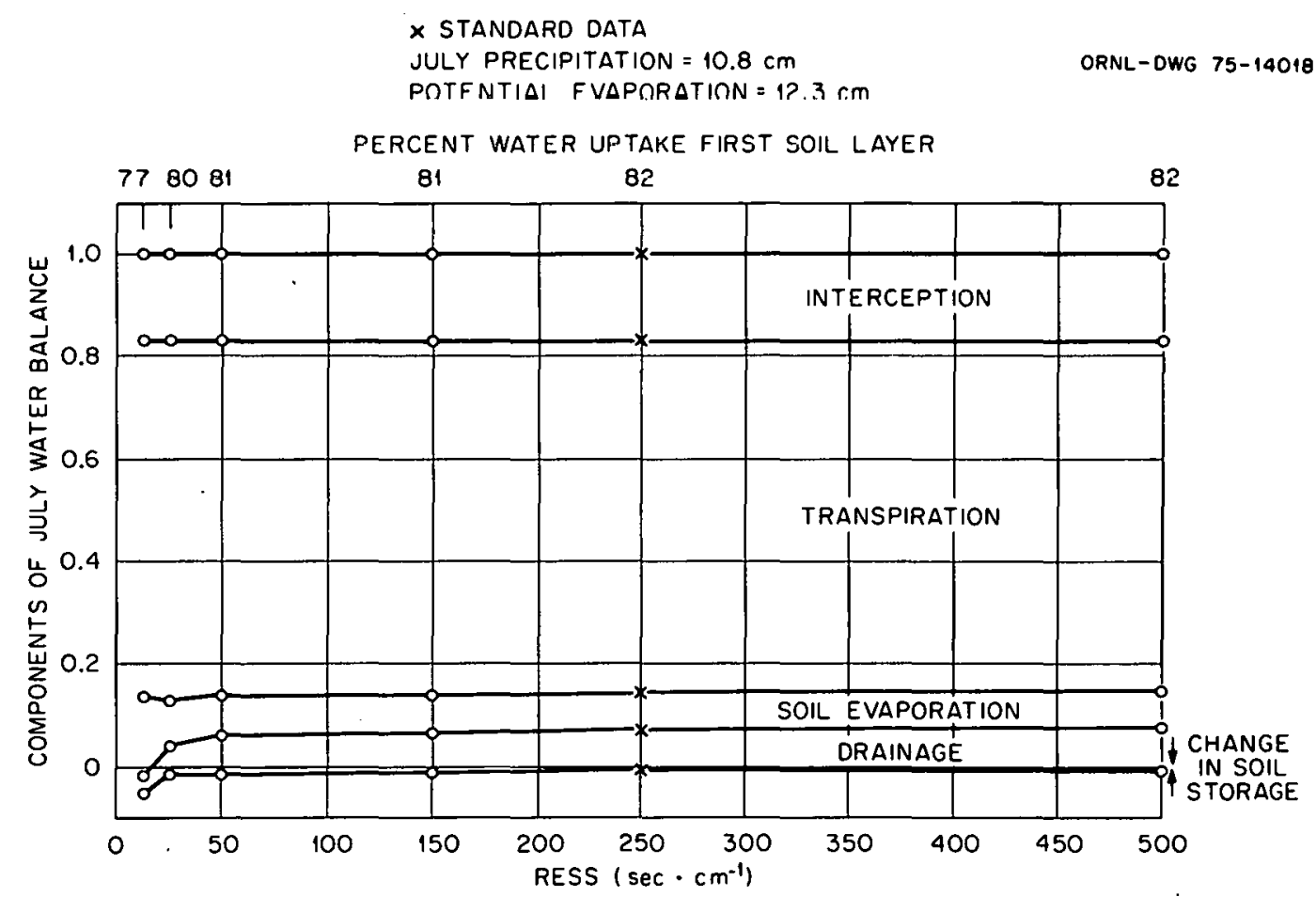

Fig. 7. Sensitivity of July water balance components to change in the maximum resistance of the evapotranspiration surface (RESS). 
$\times$ STANDARD DATA

ORNL-DWG 75-14019

JULY PRECIPITATION $=10.8 \mathrm{~cm}$

POTENTIAL EVAPORATION $=12.3 \mathrm{~cm}$

PERCENT WATER UPTAKE FIRST SOIL LAYER 9695 85 $82 \quad 8281$ 80

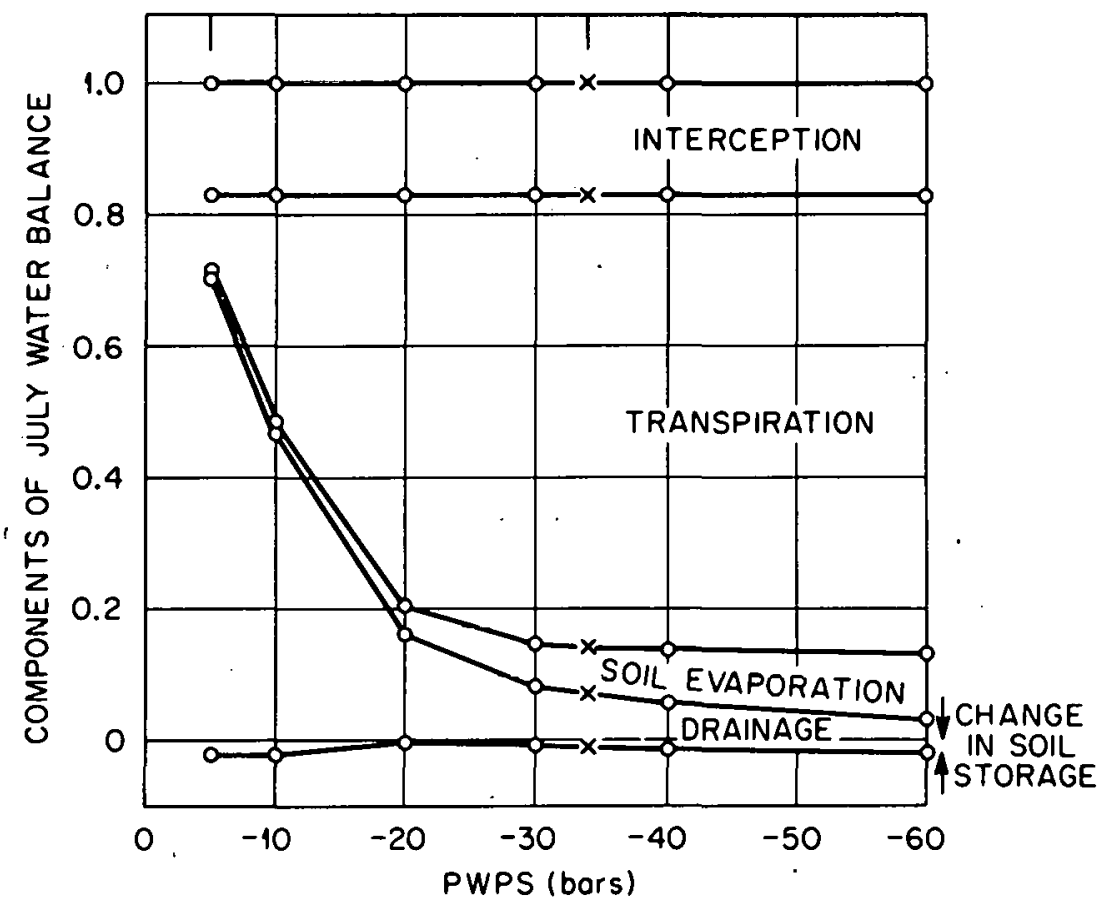

Fig. 8. Sensitivity of July water balance components to change in the surface water potential at which surface resistance becomes maximum (PWPS).

$\times$ STANDARD DATA JULY PRECIPITATION $=10.8 \mathrm{~cm}$ ORNL-DWG 75-14020 POTENTIAL EVAPORATION $=12.3 \mathrm{~cm}$

PERCENT WATER UPTAKE FIRST SOIL LAYER

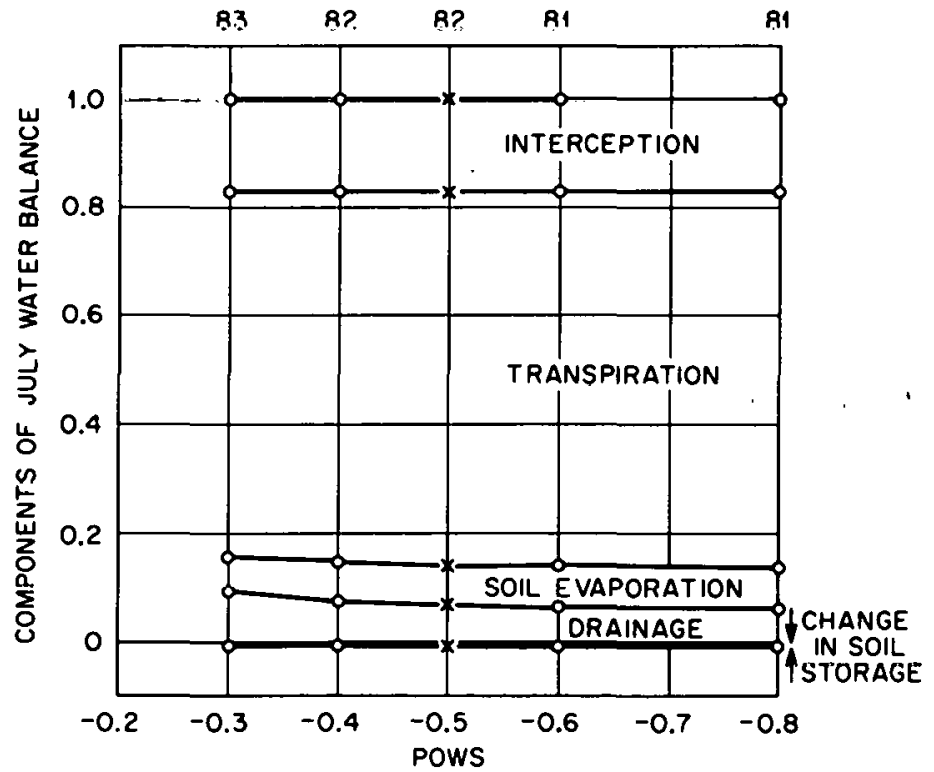

Fig. 9. Sensitivity of July water balance components to change in the exponential power term in the surface resistance equation (POWS). 
There was essentially no effect of increase in the maximum surface resistance (RESS) above $50 \mathrm{sec} / \mathrm{cm}$ on the monthly water budget (Fig. 7). Below $50 \mathrm{sec} / \mathrm{cm}$ soil water storage and soil evaporation increased and drainage decreased. Water uptake from the first soll layer showed a slight increase with increase in RESS.

Soil evaporation and transpiration showed a large decrease with increase in the surface potential for maximum surface resistance (PWPS) (Fig. 8). There was a concomitant increase in drainage and a sma11 change in soil water storage. At water poitentials below -30 , bars there were minor effects on the monthly water budget. Root water uptake was higher from the first soil layer when the transpiration was lower.

There was a small decrease in transpiration with increase in the exponential power term (POWS) above -0.4 (Fig. 9). Stomata tend to respond to water stress with an almost on-off response at a critical water potential. This is best described by small pows values eg. $<-0.5$. At these low values there was little sensitivity of the model for the çase examined.

Stem, Litter and Root Parameters (Fig. 10, 11, 12, 13, 14)

The resistance to water flow in the stem (RSTEM) had a significant influence on the components of the monthly water budget (Fig. 10). Transpiration decreased with increase in RSTEM and this was accompanied by an increase in soil evaporation and drainage. The higher resistance caused less water loss through the vegetation and a higher soil water content and hence higher soil evaporation. 


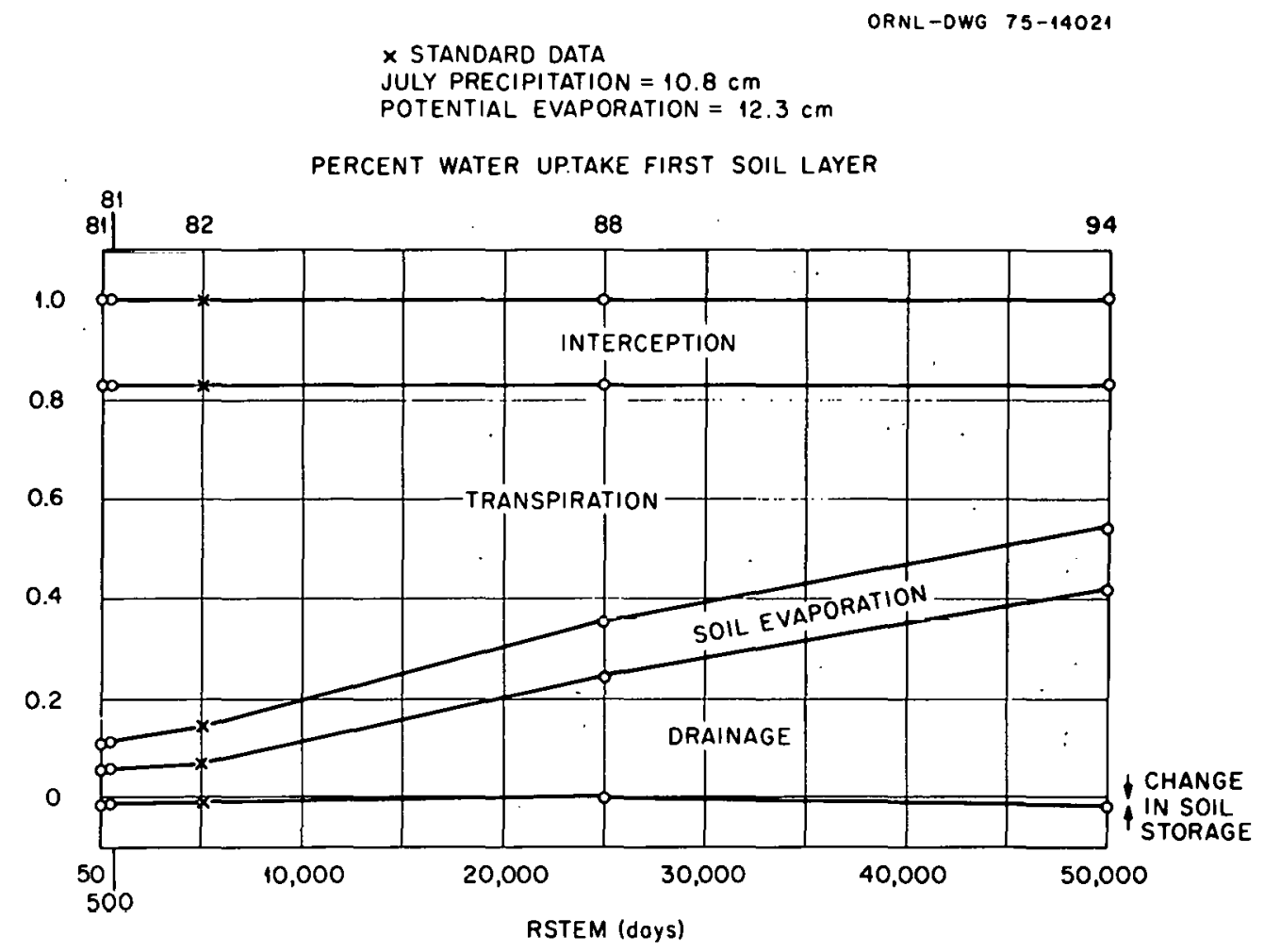

Fig. 10. Sensitivity of July water balance components to change in stem resistance (RSTEM).

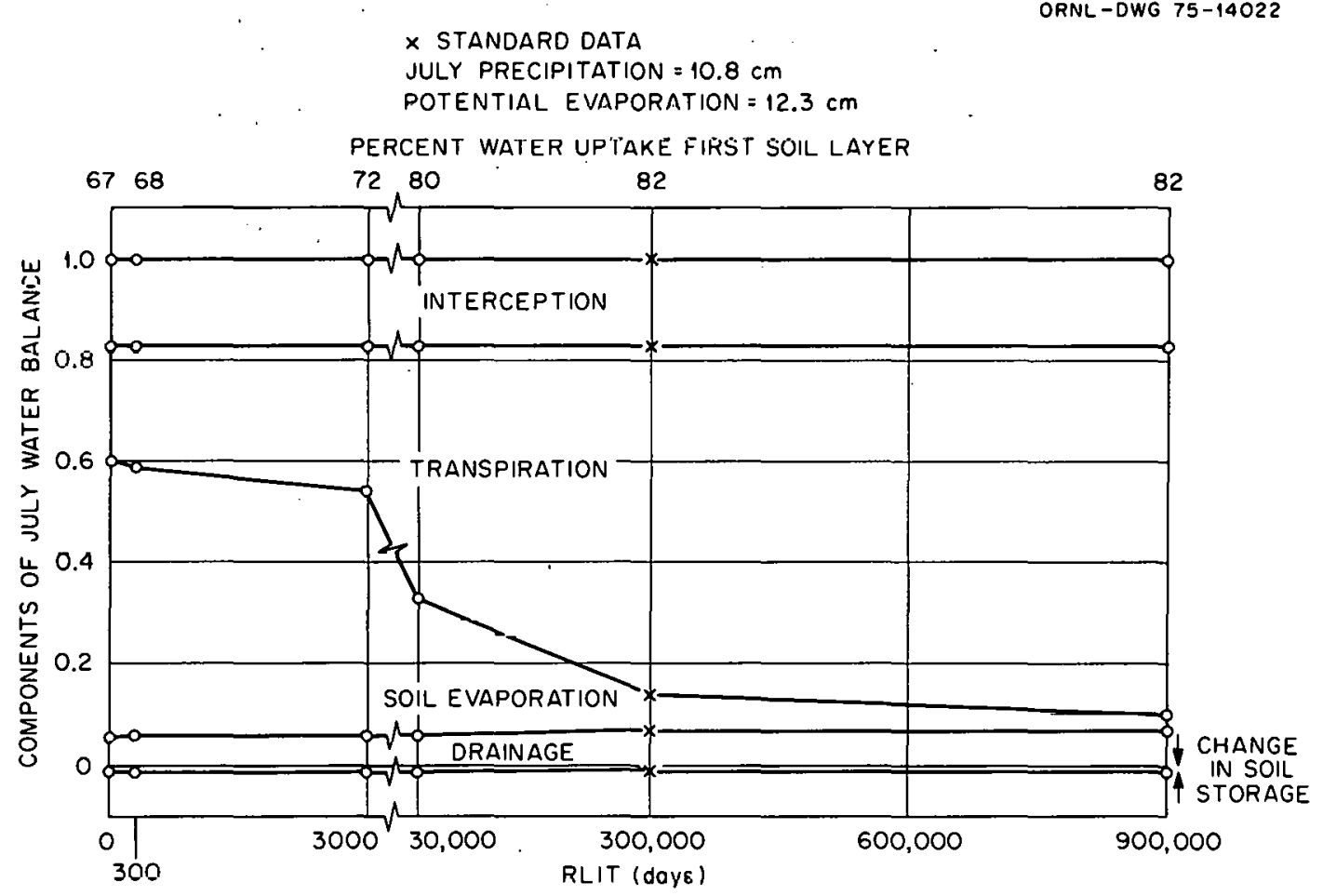

Fig. 11. Sensitivity of July water balance components to change in litter

resistance (KLI'l'). 
$\times$ STANDARD DATA

JULY PRECIPITATION $=10.8 \mathrm{~cm}$

POTENTIAL EVAPORATION $=12.3 \mathrm{~cm}$

ARAT (1) ROOTS IN FIRST LAYER

ARAT (2) ROOTS IN SECOND LAYER

PERCENT WATER UPTAKE FIRST SOIL LAYER

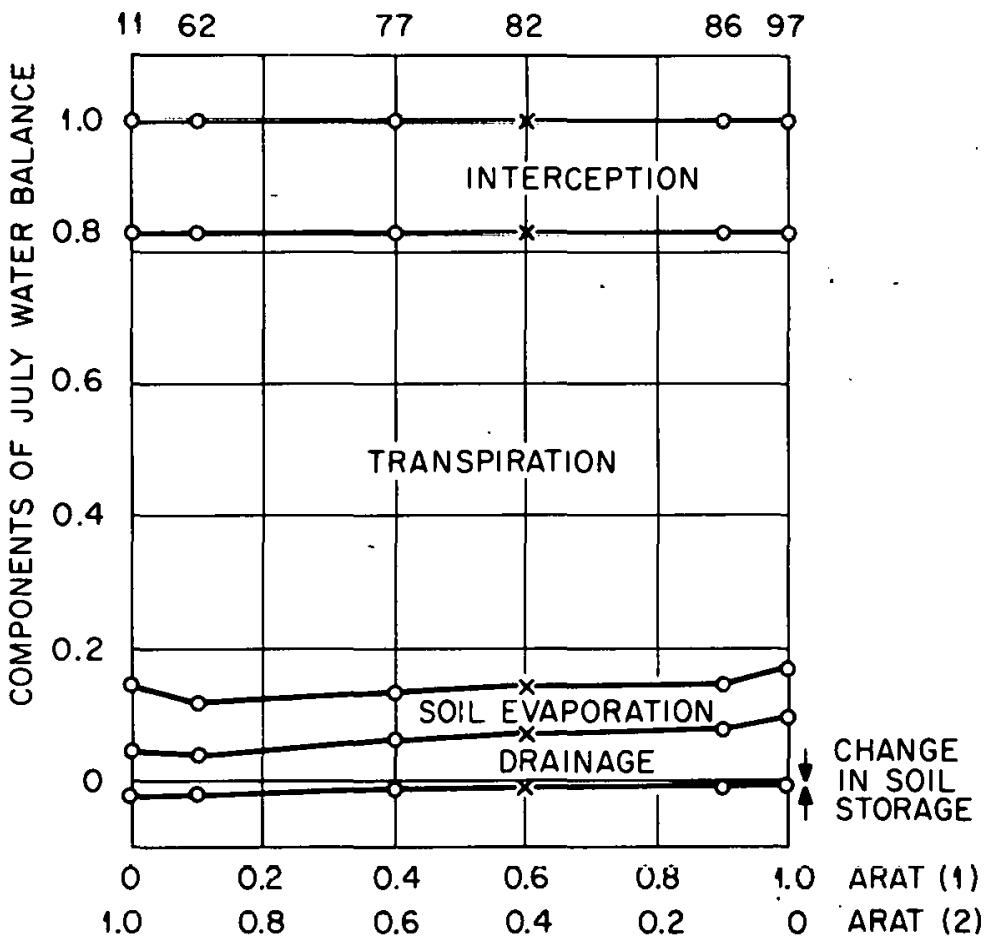

Fig. 12. Sensitivity of July water balance components to change in the porportional

distribution of roots (ARAT). (The extreme values of ARAT are 0.001 and 0.999 and not 0.0 and 1.0.) 
AT (2) $=0.01 \mathrm{~cm}^{2} \cdot \mathrm{cm}^{-2}$ FOR ALL RUNS $\times$ STANDARD DATA

JULY PRECIPITATION $=10.8 \mathrm{~cm}$

POTENTIAL EVAPORATION $=12.3 \mathrm{~cm}$

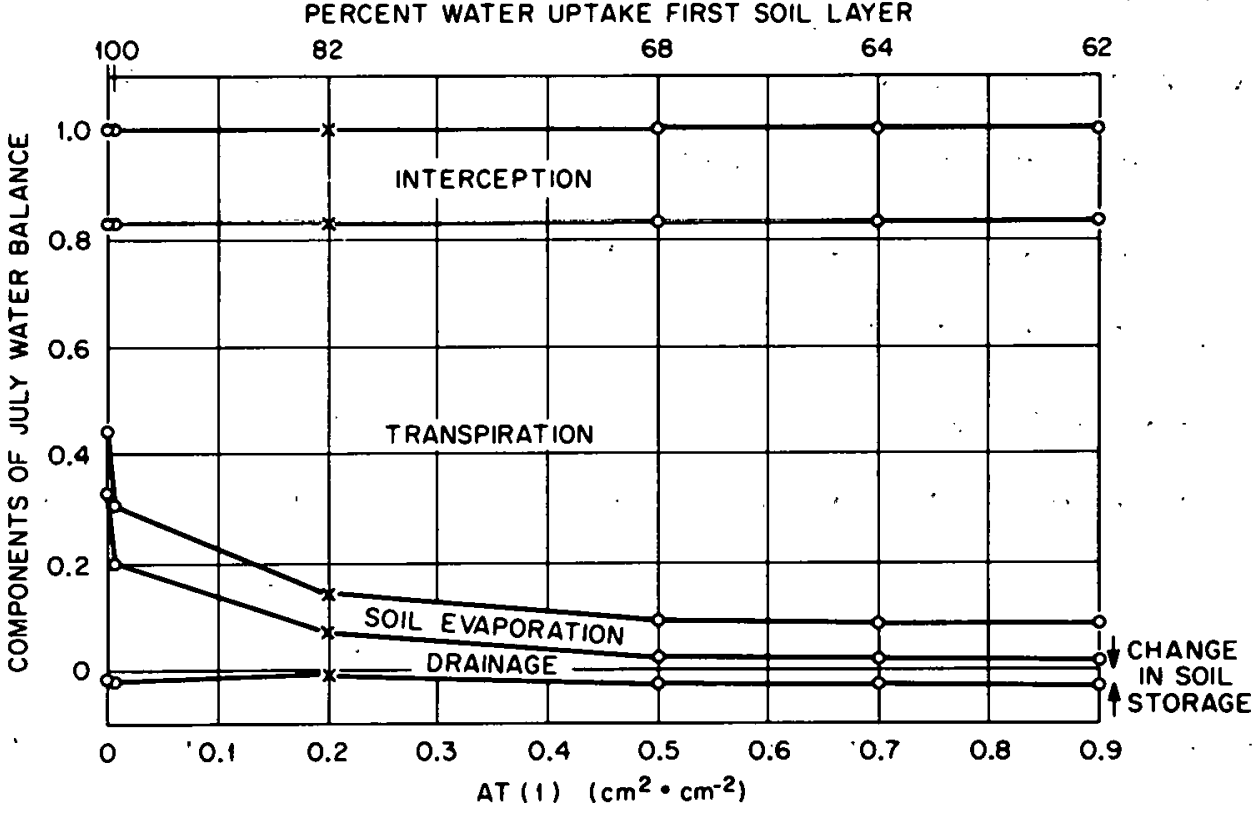

Fig. 13. Sensitivity of July water balance components to change in proportion of root

cross sectional area in the first soil

layer (AT (1)).

AT (1) $=0.2 \mathrm{~cm}^{2} \cdot \mathrm{cm}^{-2}$ FOR ALL RUNS

$\times$ STANDARO DATA

ORNL-DWG 75-14025

JULY PRECIPITATION $=10.8 \mathrm{~cm}$

POTENTIAL EVAPORATION $=12.3 \mathrm{~cm}$

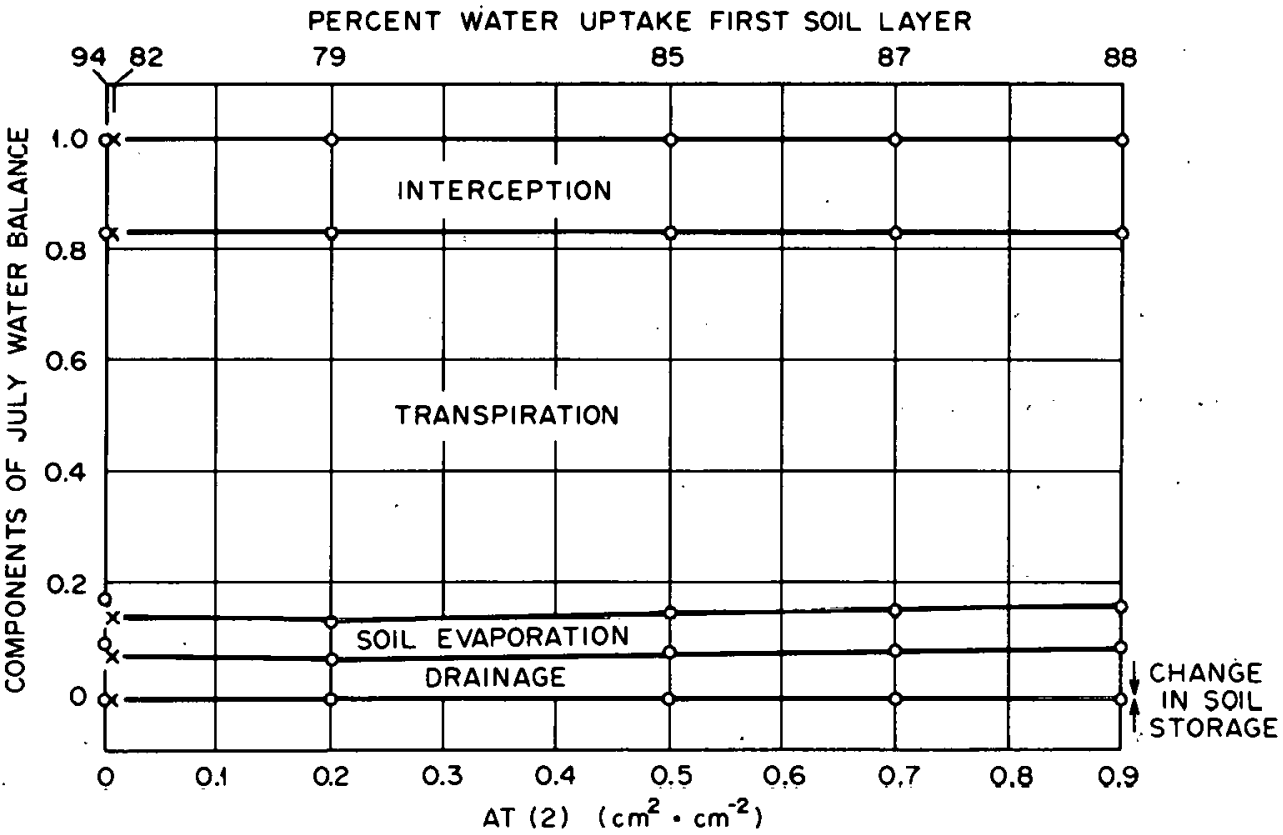

Fig. 14. Sensitivity of July water balance components to change in proportion of root cross sectional area in the second soil 
RLIT represented the effect of soil components on limiting the flow of liquid water to the soil surface. A zero value resulted in a large amount of soil evaporation (Fig. 11). There was a decrease in soil evaporation and an increase in transpiration with increase in RLIT. Drainage and soil storage were not much affected by RLIT. In contrast with other parameter effects, the water uptake from the first soil layer increased with increase in transpiration.

The proportion of roots in the first layer relative to the second (ARAT) was varied through a large range with very little effect on the components of the water budget (Fig. 12). The percentage of water taken up from the first layer however increased with increase in the proportion of roots in the first layer. The model shows that $11 \%$ of the root water uptake can take place through $0.1 \%$ of roots in the first soil layer or $97 \%$ can be taken up through $99.9 \%$ of roots in the first layer. It should be noted that the extreme values used for ARAT are 0.001 and 0.999 and not 0 and 1 (see Table 1 ).

An increase in the cross sectional area of roots up to $0.5 \mathrm{~cm}^{2} / \mathrm{cm}^{2}$. in the first soil layer AT(1) caused an increase in transpiration (F1g. 13). Drainage and soil evaporation increased as transpiration was reduced. Water uptake from the first soil layer decreased with increase in root cross-sectional area and this followed the general trend of lower uptake from the first soil layer with increase in transpiration. AT(2) was given a much lower standard value than $\operatorname{AT}(1)$ and the range of responses was much less than for AT(1) (Fig. 14). There was relatively little effect of change in $\mathrm{AT}(2)$ on the components of the water balance. 
Root Conductivity and Soil Parameters (Fig. 15, 16, 17, 18)

There is very little information on the root conductivity to water flow and an intuitive hypothesis was used in the model. Root conductivity for the first layer was made. RTCON1 times the soil hydraulic conductivity for that layer. At low RTCON1 values, transpiration was sma1l and drainage was high (Fig. 15). Increase in RTCON1 increased transpiration and decreased both soil evaporation and drainage. Water uptake from the first soil layer was proportionally decreased with higher root conductivity. This agrees with the effects of other factors where higher transpiration rates were accompanied by lower proportional uptake of water from the first layer.

In contrast with RTCON1, there was relatively little effect of RTCON2 on the monthly water balance (Fig. 16). This is probably a consequence of the higher soil hydraulic conductivity in the first soil layer. An interaction study of RTCON and the next factor, SCON would provide further insight into range of sensitivity of these factors. Increase in RTCON2 above 40 induced an increase in transpiration and a decrease in the proportion of water taken up from the first. soil layer. Saturated hydraulic conductivity is used to set the upper limit of the hydraulic conductivities of the soil layers. In the standard soil the saturated values were 150 and $75 \mathrm{~cm} /$ day for the first layer and other layers respectively. Order of magnitude increases in hydraulic conductivity (FACTOR) caused an increased in transpiration (Fig. 17). Effects on drainage and soil storage were more complicated. Runoff was generated when the conductivity FACTOR was less than 0.1 . 
ORNL-DWG 75-14026

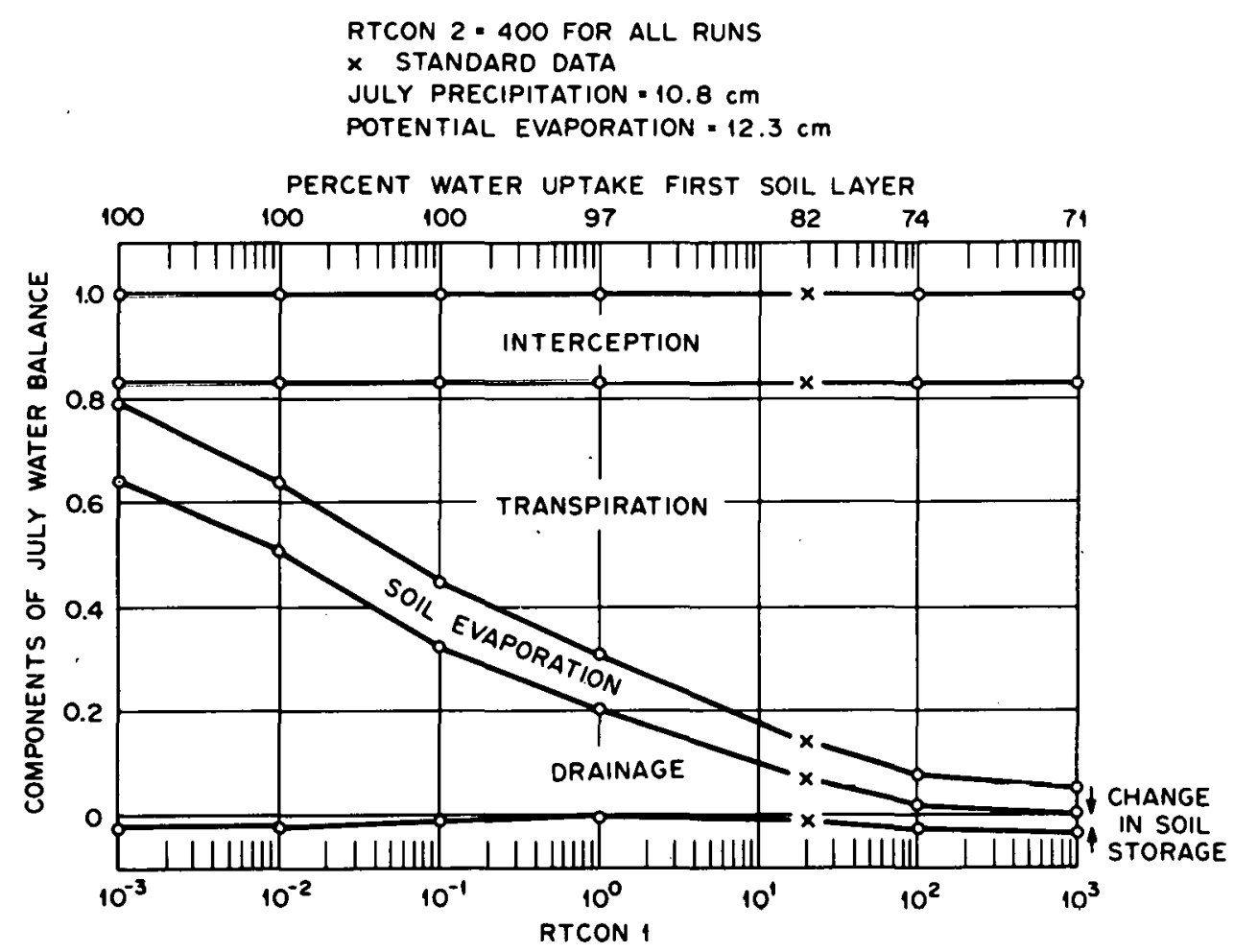

Fig. 15. Sensitivity of July water balance components to change in root conductivity factor in the first soil layer (RTCON1). $+$

ORNL-OWG 75-14027

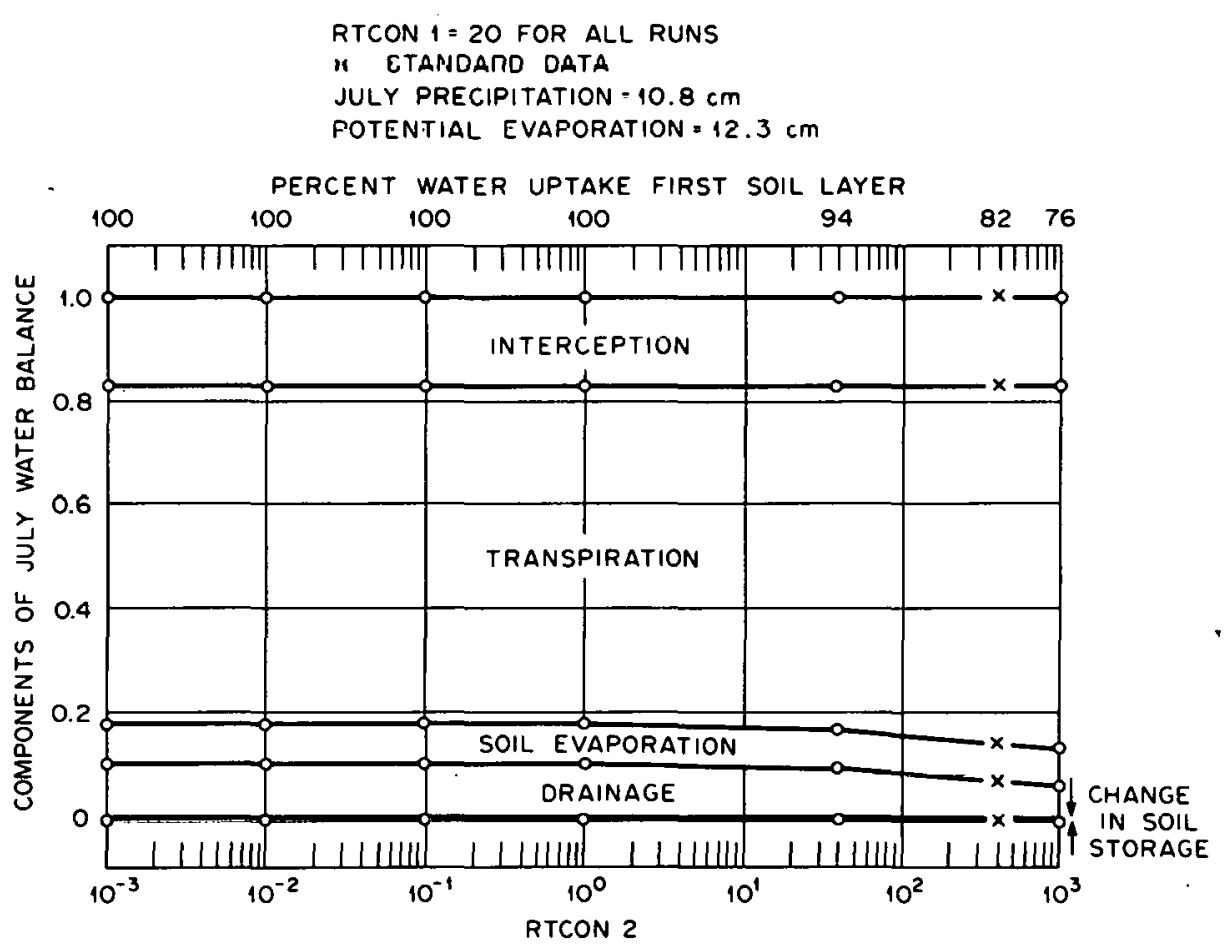

Fig. 16. Sensitivity of July water balance components to change in root conductivity factor in the second soil layer (RTCON2). 
ORNL-DWG 75-14028

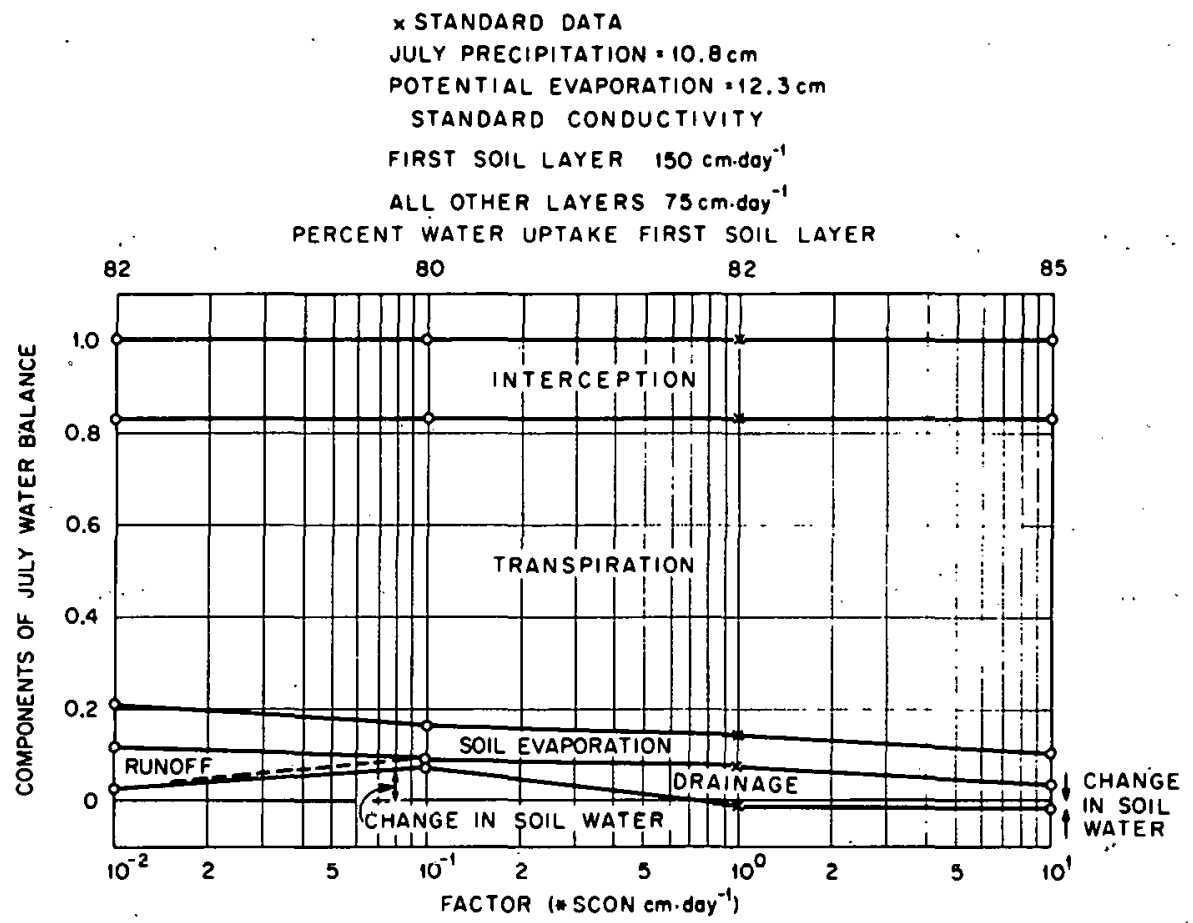

Fig. 17. Sensitivity of July water balance components to change in saturated hydraulic conductivity factor (FACTOR).

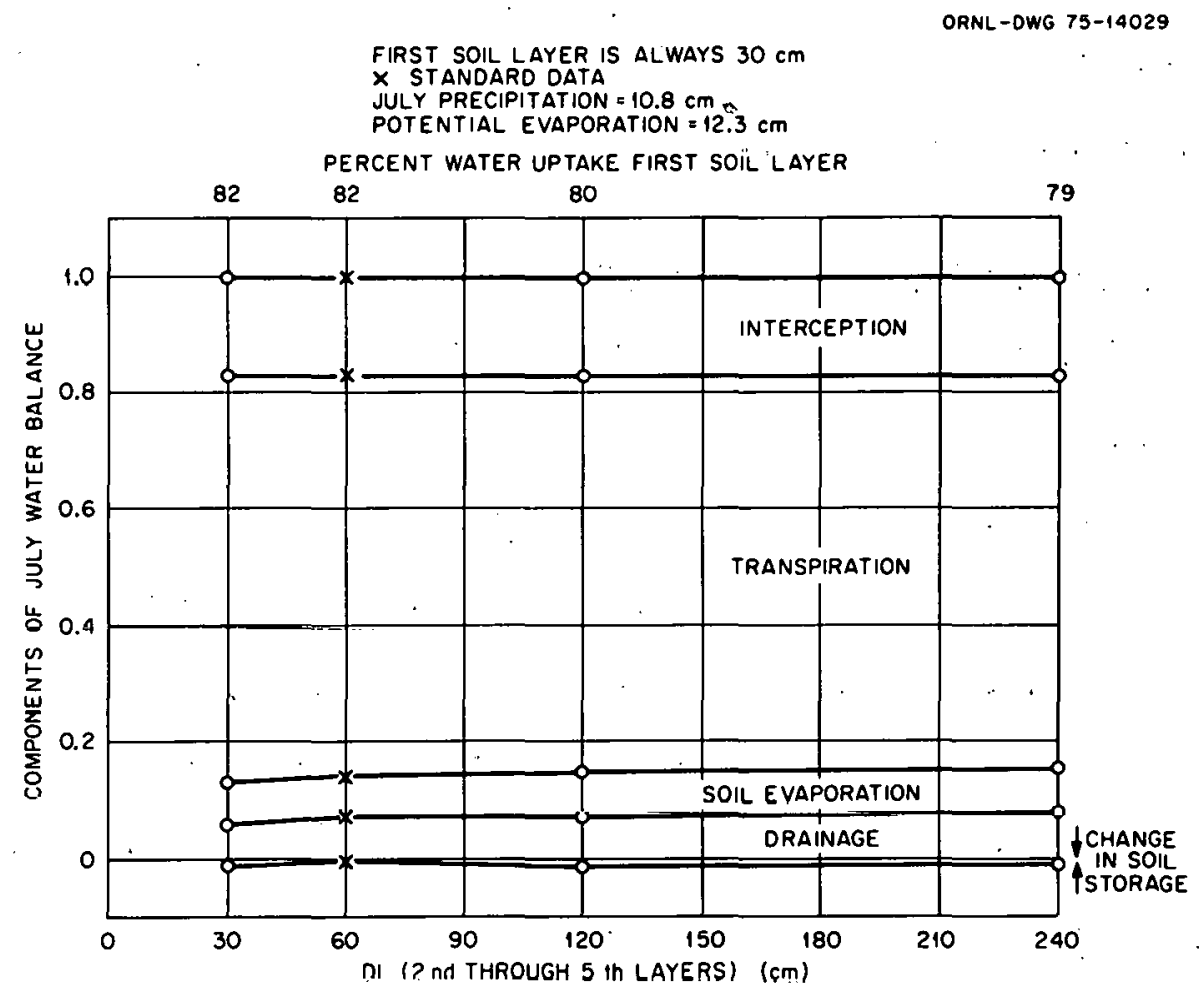

Fig. 18. Sensitivity of July water balance components to change in soil layer

thlckiless (DL). 
Change in soil layer thickness (DL) above $30 \mathrm{~cm}$ had negligible effects on the components of the water balance (Fig. 18).

Water Status of Vegetation, Daily Evapotranspiration and Drainage

The evaporation surface showed large diurnal changes in water status and this surface was perhaps the most sensitive to changes in water supply and demand. For this reason some sensitivity comparisons are given for surface water potential, conductance and evapotranspiration rate for several days following a rainfall (i.e., system increasing in stress). A rainfali of $3.1 \mathrm{~cm}$ received on $8 \mathrm{July} 1953$ (ended at $6 \mathrm{pm}$ ) was followed by six sunny days. The daily drainage rates for the same period are also presented to assess particularly soil parameter effects on short term model response. Results for the 9 th and 14 th of July are tabulated below to show the effects of change in parameters on the midday values of surface potential and conductance and daily drainage and evapotranspiration rate.

Slope and Canopy Parameters (Tables 2a, b, $c$, d)

Surface watcr potential was lower with increase in inclination for both north $\left(\operatorname{AZIM}=360^{\circ}\right)$ and south $\left(\right.$ AZIM $\left.=180^{\circ}\right)$ facing slopes (Table $\left.2 \mathrm{a}\right)$. This may seem to contradict normal experience of north facing slopes having less water stress. Surface conductance was lower with increase in inclination while the evapotranspiration rate was higher on steeper slopes. The daily drainage rate was highest at the $60^{\circ}$ slope with a south facing aspect $\left(\operatorname{AZIM}=180^{\circ}\right)$ whereas the north facing slopes had drainage rates less than the horizontal surface $\left(\right.$ INCL $=0^{\circ}$ ). The solar 
TABLE 2a

\begin{tabular}{|c|c|c|c|c|c|c|c|c|}
\hline \multicolumn{2}{|c|}{$\begin{array}{c}\text { Surface Water Potent1al } \\
\text { (bars) }\end{array}$} & \multicolumn{6}{|c|}{ DAY IN JUT,Y } & \\
\hline PARAMETER & VALUE & 9 & 10 & 11 & 12 & 13 & 14. & \\
\hline $\begin{array}{c}\text { AXIM }=180^{\circ} \\
\text { INCL } \\
\text { (degrees) }\end{array}$ & $\begin{array}{l}0 * \\
30 \\
45 \\
60 \\
75\end{array}$ & $\begin{array}{l}-18.8 \\
-19.7 \\
-20.2 \\
-21.0 \\
-22.5\end{array}$ & $\begin{array}{l}-19.3 \\
-19.9 \\
-20.3 \\
-20.9 \\
-22.3\end{array}$ & $\begin{array}{l}-22.0 \\
-21.7 \\
-22.1 \\
-22.3 \\
-23.5\end{array}$ & $\begin{array}{l}-25.2 \\
-24.3 \\
-24.6 \\
-24.2 \\
-25.3\end{array}$ & $\begin{array}{l}-27.2 \\
-26.8 \\
-26.9 \\
-26.6 \\
-27.3\end{array}$ & $\begin{array}{l}-28.5 \\
-28.2 \\
-28.3 \\
-28.1 \\
-28.6\end{array}$ & $\cdot$ \\
\hline $\begin{array}{c}\text { AZIM }=360^{\circ} \\
\text { INCL } \\
\text { (degrees) }\end{array}$ & $\begin{array}{l}30 \\
45 \\
60 \\
75\end{array}$ & $\begin{array}{l}-19.0 \\
-19.2 \\
-21.0 \\
-24.8\end{array}$ & $\begin{array}{l}-19.5 \\
-19.7 \\
-21.6 \\
-26.1\end{array}$ & $\begin{array}{l}-22.2 \\
-22.4 \\
-24.7 \\
-28.6\end{array}$ & $\begin{array}{l}-25.4 \\
-25.5 \\
-26.9 \\
-29.5\end{array}$ & $\begin{array}{l}-27.3 \\
-27.3 \\
-28.1 \\
-30.2\end{array}$ & $\begin{array}{l}-28.5 \\
-28.6 \\
-29.2 \\
-31.0\end{array}$ & $\begin{array}{c}\cdot \\
\therefore r\end{array}$ \\
\hline ALBS & 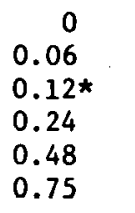 & $\begin{array}{l}-19.6 \\
-19.2 \\
-18.8 \\
-17.9 \\
-15.8 \\
-13.3\end{array}$ & $\begin{array}{l}-20.2 \\
-19.8 \\
-19.3 \\
-18.4 \\
-16.4 \\
-14.0\end{array}$ & $\begin{array}{l}-23.1 \\
-22.5 \\
-22.0 \\
-20.7 \\
-17.7 \\
-14.2\end{array}$ & $\begin{array}{l}-26.0 \\
-25.6 \\
-25.2 \\
-24.3 \\
-20.4 \\
-14.0\end{array}$ & $\begin{array}{l}-27.6 \\
-27.4 \\
-27.2 \\
-26.8 \\
-25.4 \\
-20.3\end{array}$ & $\begin{array}{l}-28.7 \\
-28.6 \\
-28.5 \\
-28.2 \\
-27.3 \\
-25.5\end{array}$ & $\cdot$ \\
\hline SDRAG & $\begin{array}{l}0.1 \\
0.4 \\
0.6 * \\
0.9\end{array}$ & $\begin{array}{l}-18.5 \\
-18.6 \\
-18.8 \\
-18.9\end{array}$ & $\begin{array}{l}-19.2 \\
-19.2 \\
-19.3 \\
-19.5\end{array}$ & $\begin{array}{l}-21.8 \\
-21.8 \\
-22.0 \\
-22.2\end{array}$ & $\begin{array}{l}-25.0 \\
-25.1 \\
-25.2 \\
-25.3\end{array}$ & $\begin{array}{l}-27.3 \\
-27.3 \\
-27.2 \\
-27.1\end{array}$ & $\begin{array}{l}-28.6 \\
-28.6 \\
-28.5 \\
-28.4\end{array}$ & \\
\hline $\begin{array}{l}\text { EPXMAX } \\
(\mathrm{cm})\end{array}$ & $\begin{array}{l}0.0001 \\
0.02 \\
0.04 \\
0.063 * \\
0.08 \\
0.10 \\
\end{array}$ & $\begin{array}{l}-18.7 \\
-18.8 \\
-18.8 \\
-18.8 \\
-18.8 \\
-18.8\end{array}$ & $\begin{array}{l}-18.9 \\
-19.2 \\
-19.2 \\
-19.3 \\
-19.4 \\
-19.4\end{array}$ & $\begin{array}{l}-20.4 \\
-21.4 \\
-21.7 \\
-22.0 \\
-22.1 \\
-22.3\end{array}$ & $\begin{array}{l}-23.3 \\
-24.7 \\
-24.9 \\
-25.2 \\
-25.3 \\
-25.4\end{array}$ & $\begin{array}{l}-26.5 \\
-27.0 \\
-27.1 \\
-27.2 \\
-27.2 \\
-27 . .3\end{array}$ & $\begin{array}{l}-28.1 \\
-28.4 \\
-28.4 \\
-28.5 \\
-28.5 \\
-28.5\end{array}$ & \\
\hline
\end{tabular}

* Indicates the standard value. 
TABLE $2 \mathrm{~b}$

\begin{tabular}{|c|c|c|c|c|c|c|c|c|c|}
\hline \multicolumn{4}{|c|}{$\begin{array}{l}\text { Surface Conductance } \\
\left(\sec ^{\circ} \mathrm{cm}^{-1}\right)\end{array}$} & \multicolumn{3}{|c|}{ DAYS IN JULY } & \multicolumn{2}{|l|}{ ' } & \\
\hline PARAMETER & VALUE & 9 & 10 & 11 & 12 & 13 & 14 & & \\
\hline \multicolumn{10}{|l|}{$A Z I M=180^{\circ}$} \\
\hline $\begin{array}{c}\text { INCL } \\
\text { (degrees) }\end{array}$ & $\begin{array}{l}0 * \\
30 \\
45 \\
60 \\
75\end{array}$ & $\begin{array}{l}.471 \\
.457 \\
.445 \\
.422 \\
.360\end{array}$ & $\begin{array}{l}.463 \\
.452 \\
.441 \\
.423 \\
.368\end{array}$ & $\begin{array}{l}.385 \\
.397 \\
.379 \\
.371 \\
.301\end{array}$ & $\begin{array}{l}.201 \\
.254 \\
.236 \\
.262 \\
.190\end{array}$ & $\begin{array}{l}.099 \\
.116 \\
.110 \\
.124 \\
.095\end{array}$ & $\begin{array}{l}.057 \\
.064 \\
.061 \\
.067 \\
.053\end{array}$ & & \\
\hline \multicolumn{10}{|l|}{$A Z I M=360^{\circ}$} \\
\hline $\begin{array}{c}\text { INCL } \\
\text { (degrees) }\end{array}$ & $\begin{array}{l}30 \\
45 \\
60 \\
75\end{array}$ & $\begin{array}{l}.468 \\
.465 \\
.420 \\
.224\end{array}$ & $\begin{array}{l}.459 \\
.456 \\
.401 \\
.146\end{array}$ & $\begin{array}{l}.371 \\
.362 \\
.231 \\
.054\end{array}$ & $\begin{array}{l}.187 \\
.179 \\
.109 \\
.036\end{array}$ & $\begin{array}{l}.095 \\
.093 \\
.066 \\
.026\end{array}$ & $\begin{array}{l}.055 \\
.055 \\
.044 \\
.017\end{array}$ & , & $\cdot$ \\
\hline ALBS & \begin{tabular}{l}
\multicolumn{1}{c}{0} \\
0.06 \\
$0.12 \star$ \\
0.24 \\
0.48 \\
0.75
\end{tabular} & $\begin{array}{l}.457 \\
.465 \\
.471 \\
.481 \\
.493 \\
.498\end{array}$ & $\begin{array}{l}.445 \\
.455 \\
.463 \\
.476 \\
.491 \\
.497\end{array}$ & $\begin{array}{l}.327 \\
.358 \\
.385 \\
.430 \\
.483 \\
.497\end{array}$ & $\begin{array}{l}.153 \\
.175 \\
.201 \\
.257 \\
.439 \\
.497\end{array}$ & $\begin{array}{l}.084 \\
.091 \\
.099 \\
.115 \\
.189 \\
.443\end{array}$ & $\begin{array}{l}.050 \\
.054 \\
.057 \\
.065 \\
.093 \\
.180\end{array}$ & & \\
\hline SDRAG & $\begin{array}{l}0.1 \\
0.4 \\
0.6 * \\
0.9\end{array}$ & $\begin{array}{l}.475 \\
.473 \\
.471 \\
.469\end{array}$ & $\begin{array}{l}.465 \\
.464 \\
.463 \\
.461\end{array}$ & $\begin{array}{r}.390 \\
.391 \\
.385 \\
.371\end{array}$ & $\begin{array}{l}.208 \\
.204 \\
.201 \\
.192\end{array}$ & $\begin{array}{l}.093 \\
.095 \\
.099 \\
.100\end{array}$ & $\begin{array}{l}.053 \\
.054 \\
.057 \\
.059\end{array}$ & & . \\
\hline $\begin{array}{l}\operatorname{EYXMAX} \\
(\mathrm{cm})\end{array}$ & $\begin{array}{l}\text { U. UUUL } \\
0.02 \\
0.04 \\
0.063 * \\
0.08 \\
0.10\end{array}$ & $\begin{array}{l}.472 \\
.471 \\
.471 \\
.471 \\
.471 \\
.471\end{array}$ & $\begin{array}{l}.470 \\
.465 \\
.464 \\
.463 \\
.462 \\
.462\end{array}$ & $\begin{array}{l}.438 \\
.406 \\
.391 \\
.385 \\
.376 \\
.371\end{array}$ & $\begin{array}{l}.313 \\
.229 \\
.218 \\
.201 \\
.190 \\
.184\end{array}$ & $\begin{array}{l}.128 \\
.105 \\
.102 \\
.099 \\
.096 \\
.095\end{array}$ & $\begin{array}{l}.067 \\
.059 \\
.058 \\
.057 \\
.056 \\
.055\end{array}$ & & \\
\hline
\end{tabular}

* Indicates the standard value. 
TABLE 2c

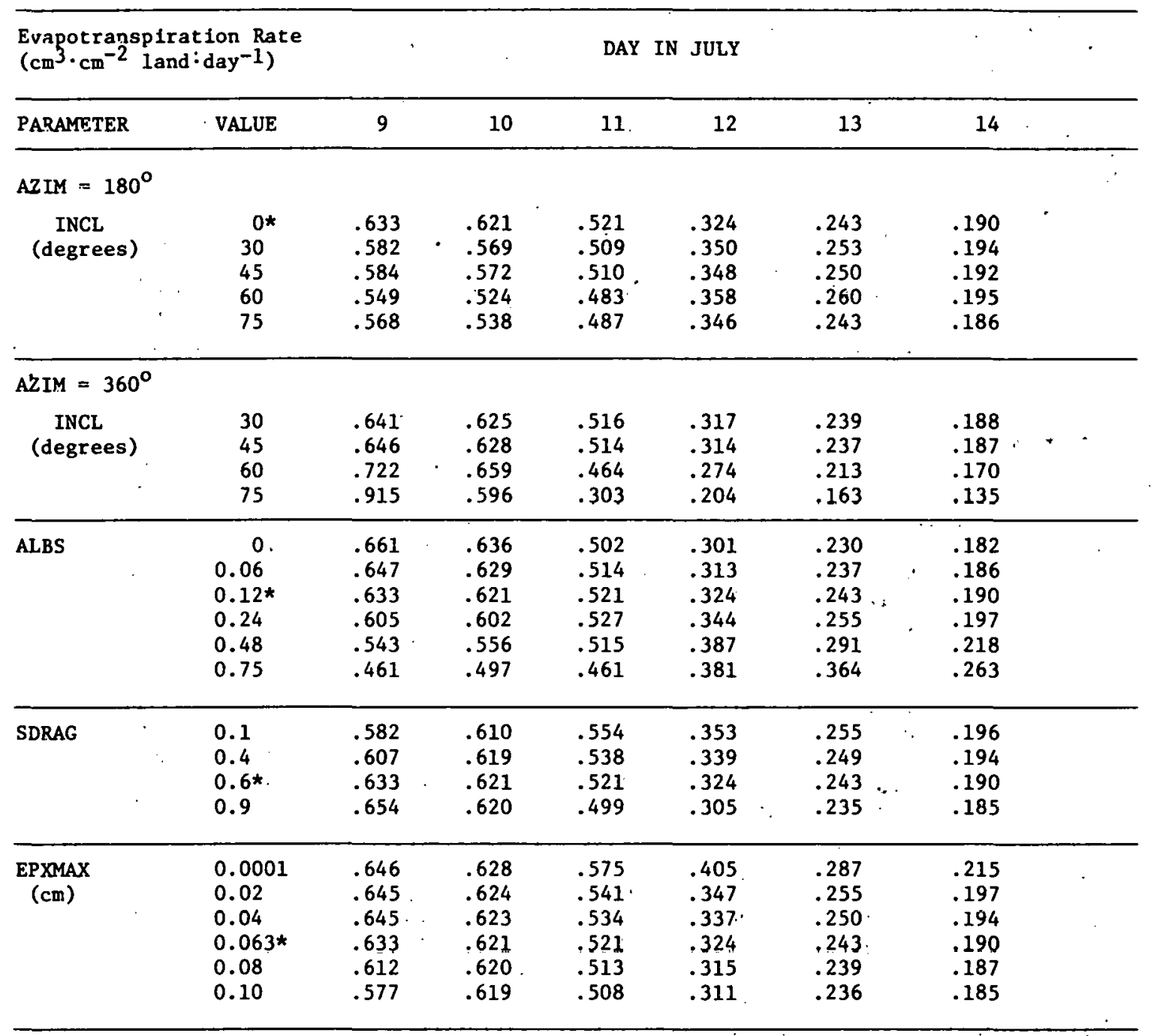

* Indicates standard value. 
TABLE 2d

\begin{tabular}{|c|c|c|c|c|c|c|c|c|}
\hline \multicolumn{4}{|c|}{$\begin{array}{l}\text { Drainage Rate } \\
\mathrm{cm} \cdot \mathrm{cm}^{-2} \text { land } \cdot \text { day }^{-1}\end{array}$} & \multicolumn{3}{|c|}{ DAYS IN JULY } & \multicolumn{2}{|c|}{$\cdot$} \\
\hline PARAMETER & VALUE & 9 & 10 & 11 & 12 & 13 & 14 & \\
\hline \multicolumn{9}{|l|}{$A Z I M=180^{\circ}$} \\
\hline $\begin{array}{c}\text { INCL } \\
\text { (degrees) }\end{array}$ & $\begin{array}{l}0 * \\
30 \\
45 \\
60 \\
75\end{array}$ & $\begin{array}{l}.029 \\
.031 \\
.031 \\
.033 \\
.030\end{array}$ & $\begin{array}{r}.028 \\
.031 \\
.030 \\
.032 \\
.029\end{array}$ & $\begin{array}{l}.027 \\
.030 \\
.030 \\
.032 \\
.029\end{array}$ & $\begin{array}{l}.027 \\
.029 \\
.029 \\
.031 \\
.028\end{array}$ & $\begin{array}{l}.026 \\
.029 \\
.029 \\
.030 \\
.028\end{array}$ & $\begin{array}{l}.026 \\
.028 \\
.028 \\
.030 \\
.028\end{array}$ & \\
\hline \multicolumn{9}{|l|}{$A Z I M=360^{\circ}$} \\
\hline $\begin{array}{c}\text { INCL } \\
\text { (degrees) }\end{array}$ & $\begin{array}{l}30 \\
45 \\
60 \\
75\end{array}$ & $\begin{array}{l}.028 \\
.028 \\
.023 \\
.015\end{array}$ & $\begin{array}{r}.027 \\
.027 \\
.023 \\
.015\end{array}$ & $\begin{array}{l}.027 \\
.027 \\
.022 \\
.014\end{array}$ & $\begin{array}{l}.026 \\
.026 \\
.022 \\
.014\end{array}$ & $\begin{array}{l}.026 \\
.026 \\
.022 \\
.014\end{array}$ & $\begin{array}{l}.025 \\
.025 \\
.021 \\
.014\end{array}$ & . \\
\hline ALBS & \begin{tabular}{l}
\multicolumn{1}{c}{0} \\
0.06 \\
$0.12 \star$ \\
0.24 \\
0.48 \\
0.75
\end{tabular} & $\begin{array}{l}.026 \\
.027 \\
.029 \\
.031 \\
.037 \\
.049\end{array}$ & $\begin{array}{l}.026 \\
.027 \\
.028 \\
.030 \\
.036 \\
.047\end{array}$ & $\begin{array}{l}.025 \\
.026 \\
.027 \\
.029 \\
.035 \\
.046\end{array}$ & $\begin{array}{l}.025 \\
.026 \\
.027 \\
.029 \\
.035 \\
.046\end{array}$ & $\begin{array}{l}.024 \\
.025 \\
.026 \\
.028 \\
.034 \\
.045\end{array}$ & $\begin{array}{l}.039 \\
.025 \\
.026 \\
.028 \\
.034 \\
.045\end{array}$ & . \\
\hline SDRAG & $\begin{array}{l}0.1 \\
0.4 \\
0.6+ \\
0.9\end{array}$ & $\begin{array}{l}.029 \\
.029 \\
.029 \\
.028\end{array}$ & $\begin{array}{l}.029 \\
.028 \\
.028 \\
.027\end{array}$ & $\begin{array}{l}.028 \\
.028 \\
.027 \\
.026\end{array}$ & $\begin{array}{l}.028 \\
.027 \\
.027 \\
.026\end{array}$ & $\begin{array}{l}.027 \\
.027 \\
.026 \\
.025\end{array}$ & $\begin{array}{l}.027 \\
.026 \\
.026 \\
.02,5\end{array}$ & \\
\hline $\begin{array}{l}\text { EPXMAX } \\
(\mathrm{cm})\end{array}$ & $\begin{array}{l}0.0001 \\
0.02 \\
0.04 \\
0.063 * \\
0.08 \\
0.10 .\end{array}$ & $\begin{array}{l}.038 \\
.032 \\
.030 \\
.029 \\
.027 \\
.026\end{array}$ & $\begin{array}{l}.037 \\
.031 \\
.029 \\
.028 \\
.027 \\
.025\end{array}$ & $\begin{array}{l}.037 \\
.030 \\
.029 \\
.027 \\
.026 \\
.025\end{array}$ & $\begin{array}{l}.036 \\
.030 \\
.028 \\
.027 \\
.026 \\
.025\end{array}$ & $\begin{array}{l}.036 \\
.029 \\
.028 \\
.026 \\
.025 \\
.024\end{array}$ & $\begin{array}{l}.036 \\
.029 \\
.027 \\
.026 \\
.025 \\
.024\end{array}$ & \\
\hline
\end{tabular}

* indicates standard value. 
radiation is adjusted to a horizontal surface basis in the model. Thus a $75^{\circ}$ slope has $3.86 \mathrm{~cm}^{2}$ of slope surface and a horizontal projection of $1 \mathrm{~cm}^{2}$. The increase in slope surface area with increase in inclination increases the radiation on the projected horizontal surface.

Increase in albedo (ALBS) caused an increase in both surface water potential and conductance and a decrease in daily evapotranspiration rate. The reduced energy load on the vegetation with higher albedo values reduced water loss from the soil and allowed a higher water potential in the vegetation. The reduction in evapotranspiration with increase in ALBS was accompanied by an increase in drainage rate.

The boundary layer resistance to heat and vapor loss from the vegetation is reduced with lower wind speeds that occur with higher values for the canopy drag coefficient (SDRAG). A large increase in the drag coefficient caused a small decrease in both surface potential and conductance and an increase in evapotranspiration rate and a slight decrease in drainage rate.

Increase in interception storage maximum (EPXMAX) had almost no effect on surface water potential or conductance. Evapotranspiration rate was reduced with increase in interception storage above $0.06 \mathrm{~cm}$. Drainage rates were considerab1.y higher with lower values in EPXMAX. This trend was maintained through the six day period.

Leaf Parameters (Tables $3 a, b, c$, d)

Increase in leaf area index (ALMAX) was associated with increases in both surface water potential and conductance although there were less effects above a leaf area index of 6 . Evapotranspiration rate 
TABLE 3a

\begin{tabular}{|c|c|c|c|c|c|c|c|}
\hline \multicolumn{2}{|c|}{$\begin{array}{l}\text { Surface Water Potential } \\
\text { (bars) }\end{array}$} & \multicolumn{6}{|c|}{ DAY IN JULY } \\
\hline PARAMETER & VALUE & 9 & 10 & 11 & 12 & 13 & 14 \\
\hline$\stackrel{\left(\mathrm{cm}^{2} \cdot \mathrm{cm}^{-2}\right)}{\text { ALMAX }}$ & $\begin{array}{l}0.01 \\
0.5 \\
1.0 \\
2.0 \\
4.0 \\
6.0 * \\
8.0 \\
12.0\end{array}$ & $\begin{array}{l}-30.6 \\
-28.4 \\
-26.1 \\
-22.8 \\
-19.5 \\
-18.8 \\
-18.7 \\
-18.8\end{array}$ & $\begin{array}{l}-30.2 \\
-28.0 \\
-25.8 \\
-22.6 \\
-19.8 \\
-19.3 \\
-19.3 \\
-19.6\end{array}$ & $\begin{array}{l}-30.3 \\
-28.2 \\
-25.9 \\
-23.2 \\
-21.7 \\
-22.0 \\
-22.4 \\
-23.1\end{array}$ & $\begin{array}{l}-30.4 \\
-28.2 \\
-25.9 \\
-23.6 \\
-24.2 \\
-25.2 \\
-25.7 \\
-26.2\end{array}$ & $\begin{array}{l}-30.4 \\
-28.3 \\
-26.1 \\
-25.1 \\
-26.7 \\
-27.2 \\
-27.4 \\
-27.7\end{array}$ & $\begin{array}{l}-30.9 \\
-28.8 \\
-26.9 \\
-27.1 \\
-28.2 \\
-28.5 \\
-28.6 \\
-28.8\end{array}$ \\
\hline $\begin{array}{l}\text { TMS } \\
\left(\sec \cdot \mathrm{cm}^{-1}\right)\end{array}$ & $\begin{array}{l}0 \\
1 \\
2^{\star} \\
4 \\
5 \\
10 \\
15\end{array}$ & $\begin{array}{l}-23.6 \\
-21.9 \\
-18.8 \\
-12.7 \\
-10.8 \\
-6.24 \\
-4.40\end{array}$ & $\begin{array}{l}-24.5 \\
-22.7 \\
-19.3 \\
-12.1 \\
-10.2 \\
-5.61 \\
-3.90\end{array}$ & $\begin{array}{l}-26.8 \\
-25.1 \\
-22.0 \\
-12.8 \\
-10.5 \\
-5.75 \\
-3.98\end{array}$ & $\begin{array}{l}-27.7 \\
-26.9 \\
-25.2 \\
-13.2 \\
-10.5 \\
-5.60 \\
-3.90\end{array}$ & $\begin{array}{l}-28.5 \\
-28.0 \\
-27.2 \\
-18.2 \\
-12.3 \\
-5.95 \\
-4.13\end{array}$ & $\begin{array}{l}-29.3 \\
-29.0 \\
-28.5 \\
-25.8 \\
-19.5 \\
-7.30 \\
-5.02\end{array}$ \\
\hline $\begin{array}{l}\text { RESS } \\
\left(\sec \cdot \mathrm{cm}^{-1}\right)\end{array}$ & $\begin{array}{l}10 \\
25 \\
50 \\
150 \\
250 * \\
\text { SUU }\end{array}$ & $\begin{array}{l}-20.2 \\
-19.4 \\
-19.3 \\
-19.0 \\
-18.8 \\
-18.4\end{array}$ & $\begin{array}{l}-27.6 \\
-20.6 \\
-20.2 \\
-19.7 \\
-19.3 \\
-18.8\end{array}$ & $\begin{array}{l}-33.5 \\
-26.9 \\
-24.8 \\
-22.8 \\
-22.0 \\
-20.8\end{array}$ & $\begin{array}{l}-47.0 \\
-30.7 \\
-28.8 \\
-26.3 \\
-25.2 \\
-23.6\end{array}$ & $\begin{array}{l}-81.8 \\
-32.3 \\
-30.6 \\
-28.2 \\
-27.2 \\
-25.8\end{array}$ & $\begin{array}{l}-181 . \\
-33.6 \\
-31.9 \\
-29.5 \\
-28.5 \\
-29.1\end{array}$ \\
\hline $\begin{array}{l}\text { PWPS } \\
\text { (bars) }\end{array}$ & $\begin{array}{l}-5 \\
-10 \\
-20 \\
-30 \\
-34^{\star} \\
-40 \\
-60\end{array}$ & $\begin{array}{l}-1.57 \\
-4.22 \\
-11.1 \\
-17.4 \\
-18.8 \\
-19.4 \\
-19.5\end{array}$ & $\begin{array}{l}-1.45 \\
-4.02 \\
-10.9 \\
-17.5 \\
-19.3 \\
-20.4 \\
-21.0\end{array}$ & $\begin{array}{l}-1.47 \\
-4.06 \\
-11.1 \\
-18.8 \\
-22.0 \\
-26.4 \\
-33.8\end{array}$ & $\begin{array}{l}-1.47 \\
-4.03 \\
-11.1 \\
-20.8 \\
-25.2 \\
-31.3 \\
-51.0\end{array}$ & $\begin{array}{l}-1.52 \\
-4.13 \\
-11.9 \\
-23.0 \\
-27.2 \\
-33.2 \\
-53.1\end{array}$ & $\begin{array}{l}-1.70 \\
-4.45 \\
-13.4 \\
-24.4 \\
-28.5 \\
-34.5 \\
-54.5\end{array}$ \\
\hline POWS & $\begin{array}{l}-.3 \\
-.4 \\
-. .5 \\
-.6 \\
-.8\end{array}$ & $\begin{array}{l}-15.5 \\
-17.7 \\
-18.8 \\
-18.8 \\
-19.2 \\
-19.4\end{array}$ & $\begin{array}{l}-15.4 \\
-17.9 \\
-19.3 \\
-19.3 \\
-20.0 \\
-20.4 \\
\end{array}$ & $\begin{array}{l}-16.3 \\
-19.7 \\
-22.0 \\
-22.0 \\
-23.6 \\
-25.6\end{array}$ & $\begin{array}{l}-18.0 \\
-22.6 \\
-25.2 \\
-25.2 \\
-26.8 \\
-28.7\end{array}$ & $\begin{array}{l}-21.6 \\
-25.3 \\
-27.2 \\
-27.2 \\
-28.4 \\
-29.8 \\
\end{array}$ & $\begin{array}{l}-24.1 \\
-27.0 \\
-28.5 \\
-28.5 \\
-29.4 \\
-30.6\end{array}$ \\
\hline
\end{tabular}

* Indicates standerd value. 
TABLE 3b

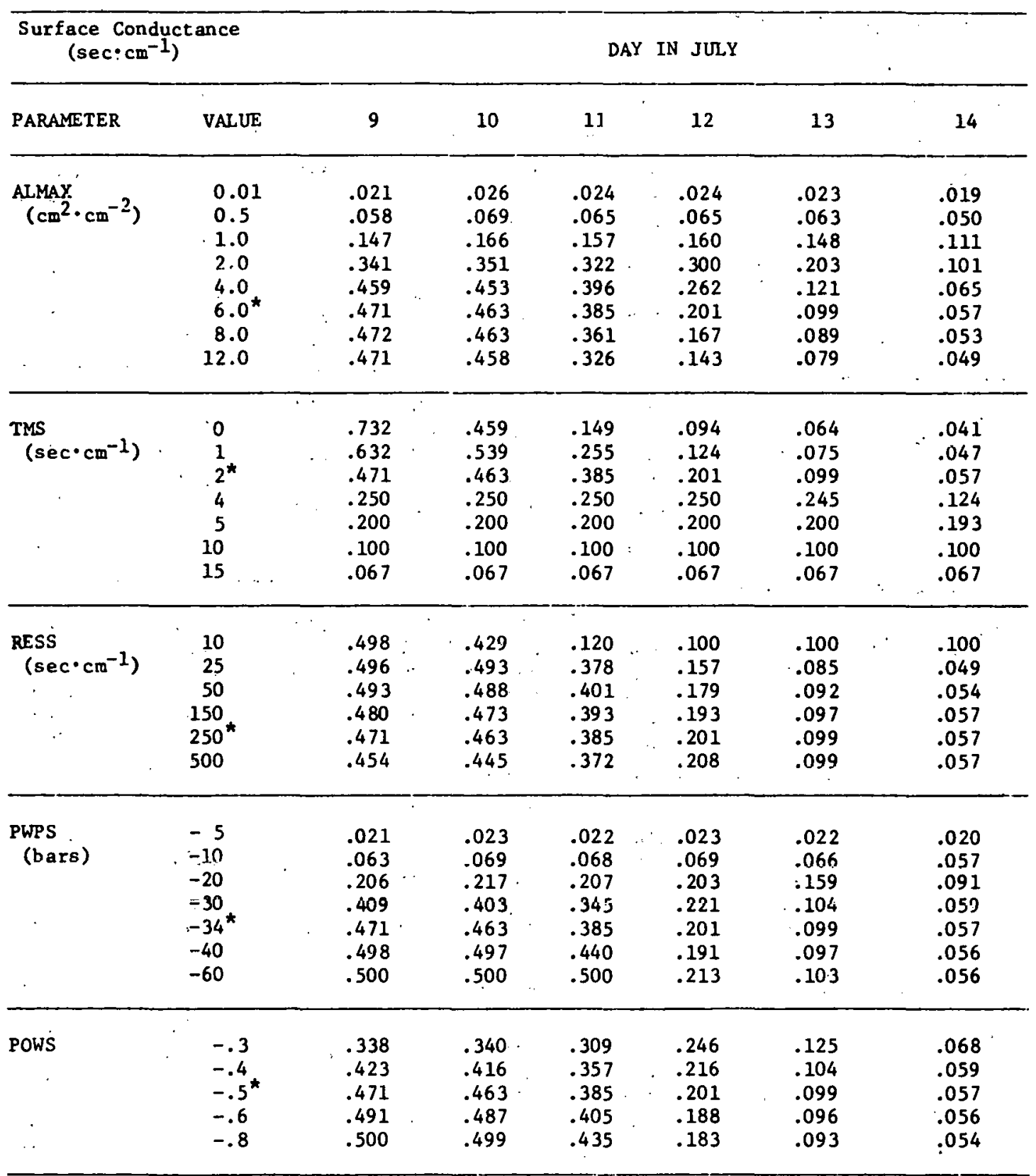

* Indicates standard value. 
TABLE 3c

\begin{tabular}{|c|c|c|c|c|c|c|c|}
\hline \multicolumn{3}{|c|}{$\begin{array}{c}\text { Evapotranspiration Rate } \\
\left(\mathrm{cm}^{3} \cdot \mathrm{cm}^{-2} \text { land } \cdot \text { day }^{-1}\right)\end{array}$} & \multicolumn{5}{|c|}{ DAY IN JULY } \\
\hline PARAMETER & VALUE & 9 & 10 & 11 & 12 & 13 & 14 \\
\hline$\stackrel{\text { ALMAX }}{\left(\mathrm{cm}^{2} \cdot \mathrm{cm}^{-2}\right)}$ & $\begin{array}{c}0.01 \\
0.5 \\
1.0 \\
2.0 \\
4.0 \\
6.0 * \\
8.0 \\
12.0\end{array}$ & $\begin{array}{l}.059 \\
.137 \\
.285 \\
.478 \\
.592 \\
.633 \\
.658 \\
.685\end{array}$ & $\begin{array}{l}.061 \\
.139 \\
.280 \\
.463 \\
.579 \\
.621 \\
.644 \\
.667\end{array}$ & $\begin{array}{l}.061 \\
.136 \\
.272 \\
.436 \\
.516 \\
.521 \\
.512 \\
.494\end{array}$ & $\begin{array}{l}.059 \\
.131 \\
.254 \\
.372 \\
.359 \\
.324 \\
.303 \\
.283\end{array}$ & $\begin{array}{l}.061 \\
.136 \\
.261 \\
.329 \\
.263 \\
.243 \\
.234 \\
.226\end{array}$ & $\begin{array}{l}.062 \\
.137 \\
.255 \\
.252 \\
.200 \\
.190 \\
.185 \\
.180\end{array}$ \\
\hline $\begin{array}{l}\text { TMS } \\
\left(\sec \cdot \mathrm{cm}^{-1}\right)\end{array}$ & $\begin{array}{c}0 \\
1 \\
2^{*} \\
4 \\
5 \\
10 \\
15\end{array}$ & $\begin{array}{l}.929 \\
.778 \\
.633 \\
.425 \\
.363 \\
.210 \\
.148\end{array}$ & $\begin{array}{l}.767 \\
.718 \\
.621 \\
.406 \\
.342 \\
.191 \\
.133\end{array}$ & $\begin{array}{r}.383 \\
.459 \\
.521 \\
.396 \\
.334 \\
.188 \\
.131\end{array}$ & $\begin{array}{r}.232 \\
.266 \\
.324 \\
.356 \\
.304 \\
.176 \\
.124\end{array}$ & $\begin{array}{r}.185 \\
.211 \\
.243 \\
.371 \\
.329 \\
.191 \\
.134\end{array}$ & $\begin{array}{l}.151 \\
.168 \\
.190 \\
.289 \\
.362 \\
.227 \\
.161\end{array}$ \\
\hline $\begin{array}{l}\text { RESS } \\
\left(\mathrm{sec}^{\prime} \mathrm{cm}^{-1}\right)\end{array}$ & $\begin{array}{c}10 \\
25 \\
50 \\
150 \\
250^{\star} \\
500\end{array}$ & $\begin{array}{l}.678 \\
.660 \\
.651 \\
.639 \\
.633 \\
.624\end{array}$ & $\begin{array}{l}.587 \\
.664 \\
.649 \\
.630 \\
.621 \\
.608\end{array}$ & $\begin{array}{l}.321 \\
.517 \\
.530 \\
.525 \\
.521 \\
.516\end{array}$ & $\begin{array}{l}.253 \\
.303 \\
.314 \\
.320 \\
.324 \\
.320\end{array}$ & $\begin{array}{l}.248 \\
.238 \\
.242 \\
.242 \\
.243 \\
.245\end{array}$ & $\begin{array}{l}.288 \\
.195 \\
.193 \\
.190 \\
.190 \\
.100\end{array}$ \\
\hline $\begin{array}{l}\text { PWPS } \\
\text { (bars) }\end{array}$ & $\begin{array}{l}-5 \\
-10 \\
-20 \\
-30 \\
-34^{\star} \\
-40 \\
-60\end{array}$ & $\begin{array}{l}.056 \\
.163 \\
.424 \\
.600 \\
.633 \\
.649 \\
.649\end{array}$ & $\begin{array}{l}.053 \\
.158 \\
.412 \\
.582 \\
.621 \\
.649 \\
.653\end{array}$ & $\begin{array}{l}.051 \\
.153 \\
.388 \\
.505 \\
.521 \\
.541 \\
.592\end{array}$ & $\begin{array}{l}.049 \\
.144 \\
.339 \\
.341 \\
.324 \\
.317 \\
.337\end{array}$ & $\begin{array}{l}.053 \\
.155 \\
.320 \\
.250 \\
.243 \\
.243 \\
.255\end{array}$ & $\begin{array}{l}.059 \\
.163 \\
.255 \\
.193 \\
.190 \\
.190 \\
.191\end{array}$ \\
\hline POWS & $\begin{array}{l}-.3 \\
-.4 \\
-.5^{\star} \\
-.6 \\
-.8\end{array}$ & $\begin{array}{l}.549 \\
.608 \\
.633 \\
.644 \\
.649\end{array}$ & $\begin{array}{l}.532 \\
.591 \\
.621 \\
.637 \\
.650\end{array}$ & $\begin{array}{l}.482 \\
.511 \\
.521 \\
.527 \\
.536\end{array}$ & $\begin{array}{r}.363 \\
.338 \\
.324 \\
.316 \\
.312\end{array}$ & $\begin{array}{l}.276 \\
.251 \\
.243 \\
.239 \\
.238\end{array}$ & $\begin{array}{l}.209 \\
.195 \\
.190 \\
.188 \\
.186\end{array}$ \\
\hline
\end{tabular}

* Indicates standard value. 
TABLE 3d

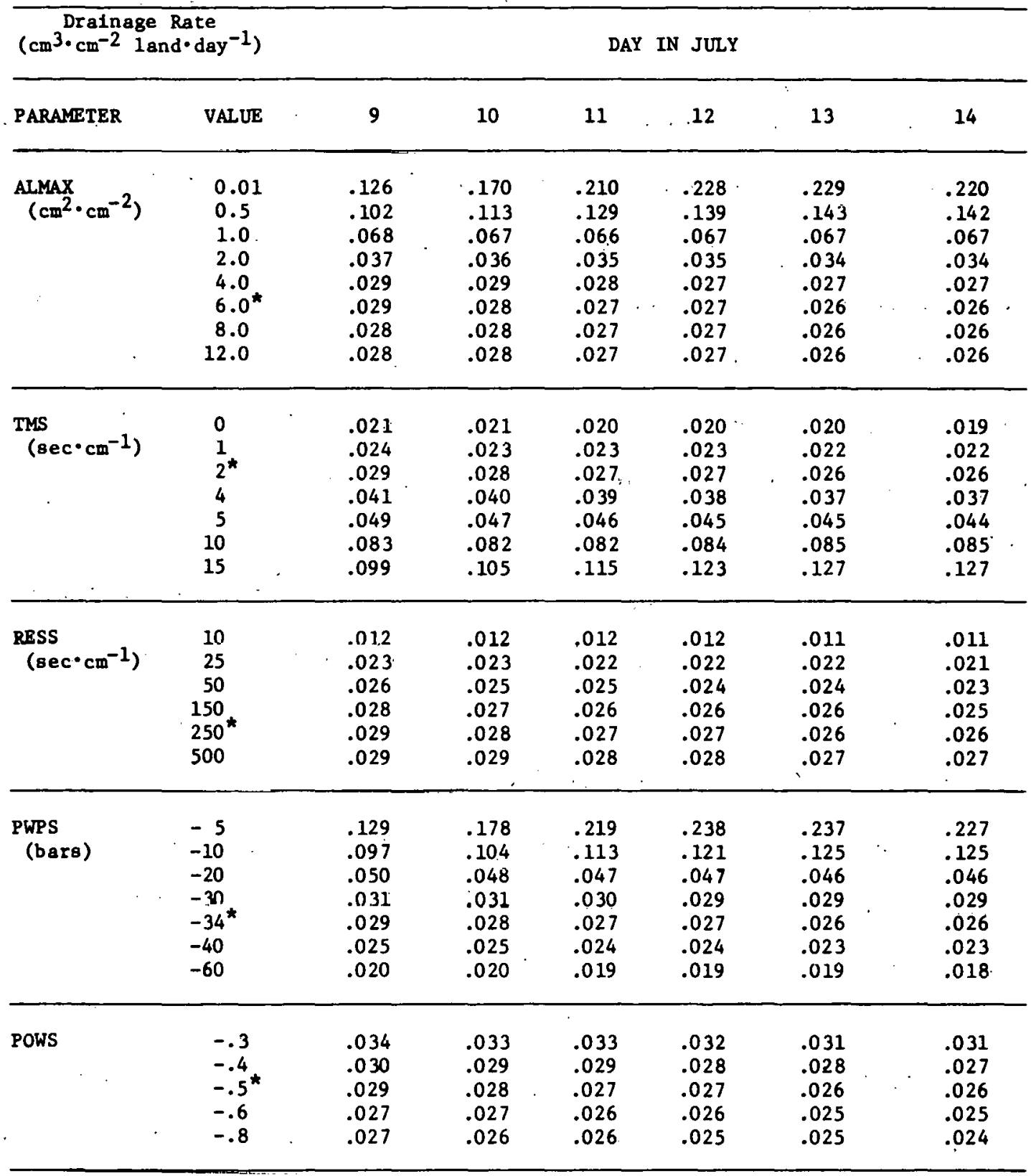

* Indicates standard value. 
increased and drainage rate decreased with increase in leaf area index. A large water loss early in the drying period induced smaller evapotranspiration rates later in the period, however the drainage rate differences increased through the six day period.

An increase in minimum surface resistance (TMS) caused an increase in surface water potential and a decrease in surface conductance. Evapotranspiration rate was greatly reduced with higher minimum resistance and the accompanying drainage rate increased. However greater water loss early in the drying period induced stress later in the period and there were less effects of TMS values on evapotranspiration later in the period. The drainage rate effects were maintained through the drying period.

Higher values of maximum surface resistance (RESS) caused lower surface potential and conductance values. Evapotranspiration was reduced and drainage was slightly increased. These trends were not consistent through the drying period.

The leaf water potential at which stomatal resistance becomes a maximum (PWPS) is an important plant characteristic that is being increasingly documented in the literature (Ritchie and Hinckley 1975). A decrease in this term was associated with a decrease in surface water potential, increase in conductance and initially higher evapotranspiration rates. A value of PWPS of -20 bars had the highest evapotranspiration rate on the 14 th day in July. Drainage rate was decreased with decrease in PWPS. 
A decrease in the exponential power term (POWS) in the surface resistance-potential equation was accompanied by a decrease in surface water potential and increases in conductance and daily evapotranspiration rate in the first part of the drying period. Conductance and evapotranspiration rate were higher at higher POWS values after the 11 th day of July. Drainage rates were higher at higher POWS values.

Stem, Litter and Root Parameters (Tables $4 a, b, c$, d) RSTEM represents the resistance of xylem vessels in the roots, trunk, branches and leaves to liquid water flow. It is generally considered that this is not the main plant resistance to water flow (Newman 1972). Nevertheless the model indicated that an increase in RSTEM induced a decrease in surface water potential, condictance and evapotranspiration rate in the first part of the drying period. There was much less effect of RSTEM on the 14th day, in July. Drainage rates were higher at higher RSTEM values and these higher rates were maintained through the six day period.

An increase in RLIT had very little effect on surface conductance, evapotranspiration rate or drainage rate although in the first part of the drying period surface potential was decreased. Figure 11 shows that there was an increase in transpiration and a decrease in soil evaporation with increase in RLIT, These effects compensated to give about the same evapotranspiration rate in the drying period.

The proportional distribution of roots (ARAT) between the two upper soil layers had a relatively small effect on the surface water relations. This analysis suggests that the soil-plant system can make 
TABLE $4 a$

\begin{tabular}{|c|c|c|c|c|c|c|c|c|}
\hline $\begin{array}{c}\text { Surface Water } \\
\text { (bars) }\end{array}$ & Potential & & & DA & IN JULY & & & \\
\hline PARAMETER & VALUE & 9 & 10 & 11 & 12 & 13 & 14 & \\
\hline $\begin{array}{l}\text { RSTEM } \\
\text { (days) }\end{array}$ & $\begin{array}{c}50 \\
500 \\
5000 \star \\
25000 \\
50000\end{array}$ & $\begin{array}{l}-0.66 \\
-2.43 \\
-18.8 \\
-27.1 \\
-28.4\end{array}$ & $\begin{array}{l}-2.02 \\
-3.75 \\
-19.3 \\
-26.8 \\
-28.1\end{array}$ & $\begin{array}{l}-10.2 \\
-11.9 \\
-22.0 \\
-26.8 \\
-28.1\end{array}$ & $\begin{array}{l}-25.5 \\
-25.5 \\
-25.2 \\
-26.7 \\
-28.0\end{array}$ & $\begin{array}{l}-27.5 \\
-27.5 \\
-27.2 \\
-26.8 \\
-28.1\end{array}$ & $\begin{array}{l}-28.7 \\
-28.7 \\
-28.5 \\
-27.4 \\
-28.6\end{array}$ & . \\
\hline $\begin{array}{l}\text { RLIT } \\
\text { (days) }\end{array}$ & $\begin{array}{r}0 \\
300 \\
3000 \\
30000 \\
300000^{\star} \\
900000\end{array}$ & $\begin{array}{l}-0.53 \\
-0.96 \\
-4.12 \\
-14.1 \\
-18.8 \\
-19.2\end{array}$ & $\begin{array}{l}-2.32 \\
-2.68 \\
-5.39 \\
-14.8 \\
-19.3 \\
-19.7\end{array}$ & $\begin{array}{l}-13.7 \\
-13.8 \\
-14.7 \\
-19.7 \\
-22.0 \\
-22.1\end{array}$ & $\begin{array}{l}-25.6 \\
-25.6 \\
-25.6 \\
-25.4 \\
-25.2 \\
-25.1\end{array}$ & $\begin{array}{l}-27.3 \\
-27.3 \\
-27.3 \\
-27.3 \\
-27.2 \\
-27.2\end{array}$ & $\begin{array}{l}-28.6 \\
-28.6 \\
-28.6 \\
-28.6 \\
-28.5 \\
-28.6\end{array}$ & \\
\hline ARAT & $\begin{array}{l}0.001 \\
0.1 \\
0.4 \\
0.6 \star \\
0.9 \\
0.999\end{array}$ & $\begin{array}{l}-19.9 \\
-19.0 \\
-18.8 \\
-18.8 \\
-18.8 \\
-18.8\end{array}$ & $\begin{array}{l}-21.9 \\
-19.8 \\
-19.4 \\
-19.3 \\
-19.3 \\
-19.3\end{array}$ & $\begin{array}{l}-23.8 \\
-22.1 \\
-22.0 \\
-22.0 \\
-22.0 \\
-22.4\end{array}$ & $\begin{array}{l}-25.0 \\
-24.2 \\
-24.9 \\
-25.2 \\
-25.2 \\
-25.9\end{array}$ & $\begin{array}{l}-26.4 \\
-26.5 \\
-27.1 \\
-27.2 \\
-27.3 \\
-27.5\end{array}$ & $\begin{array}{l}-27.6 \\
-28.2 \\
-28.4 \\
-28.5 \\
-28.3 \\
-28.6\end{array}$ & \\
\hline $\left.\operatorname{AT}(1) 3 \mathrm{~cm}^{2} \cdot \mathrm{cm}^{-2}\right)$ & $\begin{array}{l}0.001 \\
0.01 \\
0.2^{\star} \\
0.5 \\
0.7 \\
0.9\end{array}$ & $\begin{array}{l}-23.3 \\
-19.9 \\
-18.8 \\
-18.9 \\
-18.9 \\
-19.0\end{array}$ & $\begin{array}{l}-25.7 \\
-22.4 \\
-19.3 \\
-19.5 \\
-19.6 \\
-19.7\end{array}$ & $\begin{array}{l}-26.9 \\
-25.2 \\
-22.0 \\
-21.8 \\
-21.8 \\
-21.9\end{array}$ & $\begin{array}{l}-27.6 \\
-26.7 \\
-25.2 \\
-2.4 .3 \\
-24.2 \\
-24.1\end{array}$ & $\begin{array}{l}-28.4 \\
-28.0 \\
-27.2 \\
-26.5 \\
-26.4 \\
-26.3\end{array}$ & $\begin{array}{l}-29.3 \\
-29.2 \\
-28.5 \\
-28.0 \\
-27.9 \\
-27.9\end{array}$ & \\
\hline $\begin{array}{l}\operatorname{AT}(2) \\
\left(\mathrm{cm}^{2} \cdot \mathrm{cm}^{-2}\right)\end{array}$ & $\begin{array}{l}0.001 \\
0.01 * \\
0.2 \\
0.5 \\
0.7 \\
0.9\end{array}$ & $\begin{array}{l}-18.8 \\
-18.8 \\
-18.8 \\
-18.8 \\
-18.8 \\
-18.8\end{array}$ & $\begin{array}{l}-19.4 \\
-19.3 \\
-19.3 \\
-19.3 \\
-19.4 \\
-19.4\end{array}$ & $\begin{array}{l}-22.5 \\
-22.0 \\
-21.8 \\
-22.1 \\
-22.2 \\
-22.3\end{array}$ & $\begin{array}{l}-25.9 \\
-25.2 \\
-25.0 \\
-25.4 \\
-25.5 \\
-25.6\end{array}$ & $\begin{array}{l}-27.5 \\
-27.2 \\
-27.1 \\
-27.2 \\
-27.3 \\
-27.3\end{array}$ & $\begin{array}{l}-28.6 \\
-28.5 \\
-28.5 \\
-28.5 \\
-28.5 \\
-28.5\end{array}$ & \\
\hline
\end{tabular}

* Indicates standard value. 
TABLE 4b

\begin{tabular}{|c|c|c|c|c|c|c|c|c|}
\hline \multicolumn{5}{|c|}{$\begin{array}{c}\text { Surface Conductance } \\
\left(\sec ^{\cdot} \mathrm{cm}^{-1}\right)\end{array}$} & \multicolumn{3}{|c|}{ DAY IN JULY } & \multirow{2}{*}{$\frac{.}{14}$} \\
\hline PARAMETER & VALUE & & 9 & 10 & 11 & 12 & 13 & \\
\hline $\begin{array}{c}\text { RSTEM } \\
\text { (days) }\end{array}$ & * $\begin{array}{r}50 \\
500 \\
5000 * \\
25000 \\
50000\end{array}$ & & $\begin{array}{l}.500 \\
.500 \\
.471 \\
.103 \\
.060\end{array}$ & $\begin{array}{r}.500 \\
.500 \\
.463 \\
.115 \\
.068\end{array}$ & $\begin{array}{l}.500 \\
.500 \\
.385 \\
.114 \\
.071\end{array}$ & $\begin{array}{l}.182 \\
.182 \\
.201 \\
.119 \\
.069\end{array}$ & $\begin{array}{l}.087 \\
.088 \\
.099 \\
.112 \\
.066\end{array}$ & $\begin{array}{l}.051 \\
.052 \\
.057 \\
.090 \\
.054\end{array}$ \\
\hline $\begin{array}{l}\text { RLIT } \\
\text { (days) }\end{array}$ & $\begin{array}{r}0 \\
300 \\
3000 \\
30000 \\
300000^{\star} \\
900000\end{array}$ & & $\begin{array}{l}.500 \\
.500 \\
.500 \\
.497 \\
.471 \\
.465\end{array}$ & $\begin{array}{l}.500 \\
.500 \\
.500 \\
.496 \\
.463 \\
.456\end{array}$ & $\begin{array}{l}.498 \\
.498 \\
.496 \\
.456 \\
.385 \\
.380\end{array}$ & $\begin{array}{l}.174 \\
.174 \\
.175 \\
.185 \\
.201 \\
.204\end{array}$ & $\begin{array}{l}.093 \\
.093 \\
.093 \\
.095 \\
.099 \\
.096\end{array}$ & $\begin{array}{l}.054 \\
.054 \\
.054 \\
.054 \\
.057 \\
.055\end{array}$ \\
\hline $\begin{array}{c}\text { ARAT } \\
\cdot \\
\cdot .\end{array}$ & $\begin{array}{l}0.001 \\
0.1 \\
0.4 \\
0.6^{\star} \\
0.9 \\
0.999\end{array}$ & ' & $\begin{array}{l}.451 \\
.468 \\
.471 \\
.471 \\
.471 \\
.471\end{array}$ & $\begin{array}{r}.388 \\
.453 \\
.462 \\
.463 \\
.464 \\
.464\end{array}$ & $\begin{array}{l}.283 \\
.380 \\
.385 \\
.385 \\
.382 \\
.364\end{array}$ & $\begin{array}{l}.211 \\
.259 \\
.215 \\
.201 \\
.184 \\
.157\end{array}$ & $\begin{array}{r}.135 \\
.128 \\
.102 \\
.099 \\
.095 \\
.087\end{array}$ & $\begin{array}{l}.081 \\
.065 \\
.058 \\
.057 \\
.056 \\
.053\end{array}$ \\
\hline$\frac{\operatorname{AT}(1)}{\left(\mathrm{cm}^{2} \cdot \mathrm{cm}^{-2}\right)}$ & $\begin{array}{l}0.001 \\
0.01 \\
0.2^{\star} \\
0.5 \\
0.7 \\
0.9\end{array}$ & & $\begin{array}{l}.315 \\
.452 \\
.471 \\
.470 \\
.469 \\
.468\end{array}$ & $\begin{array}{r}.172 \\
.363 \\
.463 \\
.460 \\
.458 \\
.456\end{array}$ & $\begin{array}{l}.108 \\
.199 \\
.385 \\
.392 \\
.390 \\
.386\end{array}$ & $\begin{array}{l}.082 \\
.119 \\
.201 \\
.253 \\
.263 \\
.268\end{array}$ & $\begin{array}{l}.059 \\
.068 \\
.099 \\
.129 \\
.135 \\
.140\end{array}$ & $\begin{array}{l}.040 \\
.040 \\
.057 \\
.070 \\
.073 \\
.073\end{array}$ \\
\hline $\begin{array}{l}\operatorname{AI}(2) \\
\left(\mathrm{cm}^{2} \cdot \mathrm{cm}^{-2}\right)\end{array}$ & $\begin{array}{l}0.001 \\
0.01 * \\
0.2 \\
0.5 \\
0.7 \\
0.9\end{array}$ & & $\begin{array}{l}.471 \\
.471 \\
.471 \\
.471 \\
.471 \\
.471\end{array}$ & $\begin{array}{l}.462 \\
.463 \\
.463 \\
.462 \\
.462 \\
.462\end{array}$ & $\begin{array}{r}.360 \\
.385 \\
.391 \\
.377 \\
.372 \\
.369\end{array}$ & $\begin{array}{l}.158 \\
.201 \\
.211 \\
.188 \\
.181 \\
.176\end{array}$ & $\begin{array}{l}.088 \\
.099 \\
.100 \\
.096 \\
.095 \\
.093\end{array}$ & $\begin{array}{l}.053 \\
.057 \\
.057 \\
.056 \\
.056 \\
.056\end{array}$ \\
\hline
\end{tabular}

* Indicates standard value. 
TABLE $4 \mathrm{C}$

\begin{tabular}{|c|c|c|c|c|c|c|c|}
\hline \multicolumn{3}{|c|}{$\begin{array}{l}\text { Evapotranspiration Rate } \\
\left(\mathrm{cm}^{3} \cdot \mathrm{cm}^{-2} \text { land } \cdot \text { day }^{-1}\right)\end{array}$} & \multicolumn{4}{|c|}{ DAY IN JULY } & \multirow[b]{2}{*}{14} \\
\hline PARAMETER & VALUE & 9 & 10 & 11 & 12 & 13 & \\
\hline $\begin{array}{l}\text { RSTEM } \\
\text { (days) }\end{array}$ & $\begin{array}{r}50 \\
500 \\
5000^{\star} \\
25000 \\
50000\end{array}$ & $\begin{array}{l}.648 \\
.649 \\
.633 \\
.276 \\
.177\end{array}$ & $\begin{array}{l}.651 \\
.651 \\
.621 \\
.279 \\
.184\end{array}$ & $\begin{array}{l}.597 \\
.591 \\
.521 \\
.268 \\
.178\end{array}$ & $\begin{array}{r}.304 \\
.304 \\
.324 \\
.249 \\
.168\end{array}$ & $\begin{array}{l}.226 \\
.227 \\
.243 \\
.270 \\
.181\end{array}$ & $\begin{array}{l}.175 \\
.176 \\
.190 \\
.268 \\
.182\end{array}$ \\
\hline $\begin{array}{l}\text { RLIT } \\
\text { (days) }\end{array}$ & $\begin{array}{r}0 \\
300 \\
3000 \\
30000 \\
300000^{\star} \\
900000\end{array}$ & $\begin{array}{l}.650 \\
.650 \\
.650 \\
.648 \\
.633 \\
.630\end{array}$ & $\begin{array}{l}.653 \\
.653 \\
.653 \\
.649 \\
.621 \\
.617\end{array}$ & $\begin{array}{l}.555 \\
.555 \\
.558 \\
.548 \\
.521 \\
.520\end{array}$ & $\begin{array}{l}.298 \\
.298 \\
.299 \\
.310 \\
.324 \\
.326\end{array}$ & $\begin{array}{l}.232 \\
.232 \\
.232 \\
.237 \\
.243 \\
.241\end{array}$ & $\begin{array}{l}.181 \\
.181 \\
.181 \\
.184 \\
.190 \\
.187\end{array}$ \\
\hline ARAT & $\begin{array}{l}C .001 \\
0.1 \\
0.4 \\
0.6^{*} \\
0.9 \\
0.999\end{array}$ & $\begin{array}{l}.619 \\
.631 \\
.633 \\
.633 \\
.634 \\
.634\end{array}$ & $\begin{array}{l}.561 \\
.614 \\
.620 \\
.621 \\
.622 \\
.621\end{array}$ & $\begin{array}{l}.459 \\
.533 \\
.526 \\
.521 \\
.515 \\
.491\end{array}$ & $\begin{array}{l}.346 \\
.379 \\
.337 \\
.324 \\
.311 \\
.283\end{array}$ & $\begin{array}{l}.302 \\
.287 \\
.251 \\
.243 \\
.237 \\
.224\end{array}$ & $\begin{array}{l}.248 \\
.213 \\
.193 \\
.190 \\
.188 \\
.181\end{array}$ \\
\hline $\begin{array}{l}\operatorname{AT}(1) \\
\left(n m^{2} \cdot r m^{-2}\right)\end{array}$ & $\begin{array}{l}0.001 \\
0.01 \\
0.2 . \\
0.5 \\
0.7 \\
0.9\end{array}$ & $\begin{array}{l}.509 \\
.618 \\
.633 \\
.633 \\
.632 \\
.632\end{array}$ & $\begin{array}{l}.353 \\
.52 .8 \\
.621 \\
.619 \\
.617 \\
.616\end{array}$ & $\begin{array}{l}.254 \\
.367 \\
.52 .1 \\
.537 \\
.538 \\
.538\end{array}$ & $\begin{array}{l}.188 \\
.240 \\
.324 \\
.372 \\
.382 \\
.387\end{array}$ & $\begin{array}{l}.167 \\
.1 .88 \\
.243 \\
.289 \\
.299 \\
.304\end{array}$ & $\begin{array}{l}.142 \\
.144 \\
.190 \\
.220 \\
.227 \\
.229\end{array}$ \\
\hline $\begin{array}{l}\operatorname{AT}(2) \\
\quad\left(\mathrm{cm}^{2} \cdot \mathrm{cm}^{-2}\right)\end{array}$ & $\begin{array}{l}0.001 \\
0.01^{\star} \\
0.2 \\
0.5 \\
0.7 \\
0.9\end{array}$ & $\begin{array}{l}.634 \\
.633 \\
.633 \\
.633 \\
.633 \\
.633\end{array}$ & $\begin{array}{l}.619 \\
.621 \\
.622 \\
.620 \\
.620 \\
.620\end{array}$ & $\begin{array}{l}.491 \\
.521 \\
.529 \\
.512 \\
.507 \\
.503\end{array}$ & $\begin{array}{l}.287 \\
.324 \\
.332 \\
.314 \\
.308 \\
.304\end{array}$ & $\begin{array}{l}.225 \\
.243 \\
.246 \\
.239 \\
.236 \\
.234\end{array}$ & $\begin{array}{l}.181 \\
.190 \\
.191 \\
.189 \\
.187 \\
.186\end{array}$ \\
\hline
\end{tabular}

* indicates standard value. 
TABLE 4d

\begin{tabular}{|c|c|c|c|c|c|c|c|}
\hline \multicolumn{4}{|c|}{$\begin{array}{l}\text { Drainage Rate } \\
\left(\mathrm{cm}^{3} \cdot \mathrm{cm}^{-2} \text { land } \cdot \text { day }^{-1}\right)\end{array}$} & \multicolumn{3}{|c|}{ DAY IN JULY } & \multirow[b]{2}{*}{14} \\
\hline PARAMETER & VALUE & 9 & 10 & 11 & 12 & 13 & \\
\hline $\begin{array}{l}\text { RSTEM } \\
\text { (days) }\end{array}$ & $\begin{array}{r}50 \\
500 \\
5000^{\star} \\
25000 \\
50000\end{array}$ & $\begin{array}{l}.026 \\
.026 \\
.029 \\
.068 \\
.093\end{array}$ & $\begin{array}{l}.025 \\
.025 \\
.028 \\
.066 \\
.095\end{array}$ & $\begin{array}{l}.025 \\
.025 \\
.027 \\
.065 \\
.100\end{array}$ & $\begin{array}{l}.024 \\
.024 \\
.027 \\
.064 \\
.105\end{array}$ & $\begin{array}{l}.024 \\
.024 \\
.026 \\
.064 \\
.108\end{array}$ & $\begin{array}{l}.023 \\
.023 \\
.026 \\
.064 \\
.108\end{array}$ \\
\hline $\begin{array}{l}\text { RLIT } \\
\text { (days) }\end{array}$ & $\begin{array}{r}0 \\
300 \\
3000 \\
30000 \\
300000^{*} \\
900000\end{array}$ & $\begin{array}{l}.026 \\
.026 \\
.026 \\
.026 \\
.029 \\
.029\end{array}$ & $\begin{array}{l}.026 \\
.026 \\
.026 \\
.026 \\
.028 \\
.028\end{array}$ & $\begin{array}{l}.025 \\
.025 \\
.025 \\
.025 \\
.027 \\
.028\end{array}$ & $\begin{array}{l}.025 \\
.025 \\
.025 \\
.025 \\
.027 \\
.027\end{array}$ & $\begin{array}{l}.024 \\
.024 \\
.024 \\
.024 \\
.026 \\
.027\end{array}$ & $\begin{array}{l}.024 \\
.024 \\
.024 \\
.024 \\
.026 \\
.026\end{array}$ \\
\hline ARAT & $\begin{array}{l}0.001 \\
0.1 \\
0.4 \\
0.6^{\star} \\
0.9 \\
0.999\end{array}$ & $\begin{array}{l}.022 \\
.021 \\
.027 \\
.029 \\
.030 \\
.034\end{array}$ & $\begin{array}{l}.022 \\
.021 \\
.026 \\
.028 \\
.029 \\
.034\end{array}$ & $\begin{array}{l}.021 \\
.020 \\
.026 \\
.027 \\
.029 \\
.033\end{array}$ & $\begin{array}{l}.021 \\
.020 \\
.025 \\
.027 \\
.028 \\
.032\end{array}$ & $\begin{array}{l}.020 \\
.020 \\
.025 \\
.026 \\
.028 \\
.032\end{array}$ & $\begin{array}{l}.020 \\
.019 \\
.024 \\
.026 \\
.027 \\
.031\end{array}$ \\
\hline $\operatorname{AT}(1)$ & $\begin{array}{l}0.001 \\
0.01 \\
0.2^{\star} \\
0.5 \\
0.7 \\
0.9\end{array}$ & $\begin{array}{l}.081 \\
.059 \\
.029 \\
.019 \\
.017 \\
.016\end{array}$ & $\begin{array}{l}.082 \\
.058 \\
.028 \\
.018 \\
.017 \\
.016\end{array}$ & $\begin{array}{l}.086 \\
.058 \\
.027 \\
.018 \\
.016 \\
.016\end{array}$ & $\begin{array}{l}.090 \\
.058 \\
.027 \\
.018 \\
.016 \\
.016\end{array}$ & $\begin{array}{l}.092 \\
.059 \\
.026 \\
.017 \\
.016 \\
.015\end{array}$ & $\begin{array}{l}.092 \\
.059 \\
.026 \\
.017 \\
.016 \\
.015\end{array}$ \\
\hline $\begin{array}{l}\operatorname{AT}(2) \\
\left(\mathrm{cm}^{2} \cdot \mathrm{cm}^{-2}\right)\end{array}$ & $\begin{array}{l}0.001 \\
0.01^{*} \\
0.2 \\
0.5 \\
0.7 \\
0.9\end{array}$ & $\begin{array}{l}.034 \\
.029 \\
.027 \\
.030 \\
.031 \\
.031\end{array}$ & $\begin{array}{l}.033 \\
.028 \\
.027 \\
.029 \\
.030 \\
.031\end{array}$ & $\begin{array}{l}.033 \\
.027 \\
.026 \\
.029 \\
.029 \\
.030\end{array}$ & $\begin{array}{l}.032 \\
.027 \\
.026 \\
.028 \\
.029 \\
.029\end{array}$ & $\begin{array}{l}.031 \\
.026 \\
.025 \\
.028 \\
.028 \\
.029\end{array}$ & $\begin{array}{l}.031 \\
.026 \\
.025 \\
.027 \\
.028 \\
.029\end{array}$ \\
\hline
\end{tabular}

* Indicates standard value. 
internal compensations to satisfy the evaporative demand of the atmosphere. The evapotranspiration was largely determined by the atmospheric conditions and not by the soil water availability in the period from 9 to $14 \mathrm{July}$. The overall water balance for July showed small changes with change in rnot distribution (Fig. 12). There was a slightly higher drainage rate at higher ARAT values in the first soil layer.

Changes in the cross sectional area of roots in the first (AT(1)) and second soil layer (AT(2)) had relatively little effect on the surface water relations. Higher AT(1) values had higher evapotranspiration rates and conductances and lower drainage rates which were probably induced by the low standard value for AT(2). Conversely the high standard value for AT(1) dominated any effects of change in AT(2).

Root Conductivity and Soil Parameters (Tables 5a, b, c, d)

An increase in the root conductivity factor for the first soil Layer ('I'CUN1) was associated with increases in surface water potential, condictance and daily evapotranspiration rate and decreases in drainage rate. The model showed almost no response to RTCON2 except for drainage rate which was slightly reduced with increase in RTCON2. The July water balance showed a similar sensitivity to these parameters.

Increase in the saturated hydraulic conductivity factor (FACTOR) of each of the soill layers was accompanied by corresponding increases in the unsaturated hydraulic conductivity values. Nevertheless there were very little responses of surface water relations to changes in FACTOR. Drainage rate was highest with the standard conductivity factor. Lower FACTOR values reduced drainage rates whereas the highest 
TABLE $5 a$

\begin{tabular}{|c|c|c|c|c|c|c|c|}
\hline \multicolumn{3}{|c|}{$\begin{array}{c}\text { Surface Water Potential } \\
\text { (bars) }\end{array}$} & \multicolumn{4}{|c|}{ DAY IN JULY } & \multirow[b]{2}{*}{14} \\
\hline PARAMETER & VAIUE & 9 & 10 & 11 & 12 & 13 & \\
\hline RTCON 1 & $\begin{array}{c}0.001 \\
0.01 \\
0.1 \\
1.0 \\
20^{\star} \\
100 \\
1000\end{array}$ & $\begin{array}{l}-29.7 \\
-26.9 \\
-23.3 \\
-19.9 \\
-18.8 \\
-18.8 \\
-18.8\end{array}$ & $\begin{array}{l}-29.9 \\
-28.0 \\
-2.5 .7 \\
-22.4 \\
-19.3 \\
-19.2 \\
-19.2\end{array}$ & $\begin{array}{l}-30.1 \\
-28.6 \\
-26.9 \\
-25.1 \\
-22.0 \\
-21.6 \\
-21.6\end{array}$ & $\begin{array}{l}-30.2 \\
-28.9 \\
-27.6 \\
-26.6 \\
-25.2 \\
-24.4 \\
-23.9\end{array}$ & $\begin{array}{l}-30.4 \\
-29.3 \\
-28.4 \\
-28.0 \\
-27.2 \\
-26.3 \\
-26.0\end{array}$ & $\begin{array}{l}-30.8 \\
-30.0 \\
-29.3 \\
-29.2 \\
-28.5 \\
-27.9 \\
-27.8\end{array}$ \\
\hline RTCON2 & $\begin{array}{c}0.001 \\
0.01 \\
0.1 \\
1.0 \\
40 \\
400^{*} \\
1000\end{array}$ & $\begin{array}{l}-18.8 \\
-18.8 \\
-18.8 \\
-18.8 \\
-18.8 \\
-18.8 \\
-18.8\end{array}$ & $\begin{array}{l}-19.3 \\
-19.3 \\
-19.3 \\
-19.3 \\
-19.4 \\
-19.3 \\
-19.3\end{array}$ & $\begin{array}{l}-22.5 \\
-22.5 \\
-22.5 \\
-22.5 \\
-22.5 \\
-22.0 \\
-21.6\end{array}$ & $\begin{array}{l}-26.1 \\
-26.1 \\
-26.1 \\
-26.1 \\
-25.9 \\
-25.2 \\
-24.8\end{array}$ & $\begin{array}{l}-27.6 \\
-27.6 \\
-27.6 \\
-27.6 \\
-27.5 \\
-27.2 \\
-27.1\end{array}$ & $\begin{array}{l}-28.7 \\
-28.7 \\
-28.7 \\
-28.7 \\
-28.6 \\
-28.5 \\
-28.4\end{array}$ \\
\hline FACTOR & $\begin{array}{ll}\text { x } & 0.01 \\
\text { x } & 0.1 \\
\text { x } & 1.0^{\star} \\
\text { x } & 10.0\end{array}$ & $\begin{array}{l}-18.9 \\
-18.8 \\
-18.8 \\
-18.9\end{array}$ & $\begin{array}{l}-20.4 \\
-19.9 \\
-19.3 \\
-19.4\end{array}$ & $\begin{array}{l}-23.7 \\
-22.6 \\
-22.0 \\
-22.7\end{array}$ & $\begin{array}{l}-25.4 \\
-24.8 \\
-25.2 \\
-24.6\end{array}$ & $\begin{array}{l}-27.0 \\
-26.9 \\
-27.2 \\
-26.6\end{array}$ & $\begin{array}{l}-28.4 \\
-28.7 \\
-28.5 \\
-28.2\end{array}$ \\
\hline $\begin{array}{l}\mathrm{DL} \\
(\mathrm{cm})\end{array}$ & $\begin{array}{c}30 \\
60^{\star} \\
120 \\
240\end{array}$ & $\begin{array}{l}-18.7 \\
-18.8 \\
-19.0 \\
-19.1\end{array}$ & $\begin{array}{l}-19.0 \\
-19.3 \\
-20.4 \\
-21.0\end{array}$ & $\begin{array}{l}-21.0 \\
-22.0 \\
-24.5 \\
-25.3\end{array}$ & $\begin{array}{l}-24.7 \\
-25.2 \\
-26.5 \\
-26.9\end{array}$ & $\begin{array}{l}-27.2 \\
-27.2 \\
-27.6 \\
-27.7\end{array}$ & $\begin{array}{l}-28.5 \\
-28.5 \\
-28.5 \\
-28.5\end{array}$ \\
\hline
\end{tabular}

* Indicates standard value. 
TABLE 5b

\begin{tabular}{|c|c|c|c|c|c|c|c|}
\hline \multicolumn{2}{|c|}{$\begin{array}{l}\text { Surface Conductance } \\
\left(\sec ^{-} \mathrm{cm}^{-1}\right)\end{array}$} & \multicolumn{6}{|c|}{ DAY IN JULY } \\
\hline PARAMETER & VALUE & 9 & 10 & 11 & 12 & 13 & 14 \\
\hline RTCON 1 & $\begin{array}{c}0.001 \\
0.01 \\
0.1 \\
1.0 \\
20^{\star} \\
100 \\
1000\end{array}$ & $\begin{array}{l}.033 \\
.108 \\
.315 \\
.452 \\
.471 \\
.471 \\
.471\end{array}$ & $\begin{array}{l}.030 \\
.070 \\
.172 \\
.366 \\
.463 \\
.465 \\
.464\end{array}$ & $\begin{array}{l}.027 \\
.053 \\
.108 \\
.203 \\
.385 \\
.398 \\
.399\end{array}$ & $\begin{array}{l}.026 \\
.046 \\
.082 \\
.122 \\
.201 \\
.249 \\
.280\end{array}$ & $\begin{array}{l}.024 \\
.039 \\
.059 \\
.070 \\
.099 \\
.135 \\
.152\end{array}$ & $\begin{array}{l}.019 \\
.029 \\
.040 \\
.041 \\
.057 \\
.072 \\
.077\end{array}$ \\
\hline RTCON2 & $\begin{array}{c}0.001 \\
0.01 \\
0.1 \\
1.0 \\
40 \\
400^{\star} \\
1000\end{array}$ & $\begin{array}{l}.471 \\
.471 \\
.471 \\
.471 \\
.471 \\
.471 \\
.471\end{array}$ & $\begin{array}{l}.462 \\
.462 \\
.462 \\
.462 \\
.462 \\
.462 \\
.464\end{array}$ & $\begin{array}{l}.357 \\
.357 \\
.357 \\
.357 \\
.360 \\
.385 \\
.400\end{array}$ & $\begin{array}{l}.146 \\
.146 \\
.146 \\
.147 \\
.158 \\
.201 \\
.226\end{array}$ & $\begin{array}{l}.081 \\
.081 \\
.081 \\
.081 \\
.088 \\
.099 \\
.103\end{array}$ & $\begin{array}{l}.051 \\
.051 \\
.051 \\
.051 \\
.053 \\
.057 \\
.058\end{array}$ \\
\hline FACTOR & $\begin{array}{ll}\text { x } & 0.01 \\
\text { x } & 0.1 \\
\text { x } & 1.0^{\star} \\
\text { x } & 10.0\end{array}$ & $\begin{array}{l}.469 \\
.471 \\
.471 \\
.470\end{array}$ & $\begin{array}{l}.440 \\
.451 \\
.463 \\
.462\end{array}$ & $\begin{array}{l}.290 \\
.352 \\
.385 \\
.346\end{array}$ & $\begin{array}{l}.184 \\
.223 \\
.201 \\
.235\end{array}$ & $\begin{array}{l}.104 \\
.108 \\
.099 \\
.123\end{array}$ & $\begin{array}{l}.058 \\
.051 \\
.057 \\
.065\end{array}$ \\
\hline DL $(\mathrm{cm})$ & $\begin{array}{c}30 \\
60^{\star} \\
120 \\
240\end{array}$ & $\begin{array}{l}.472 \\
.471 \\
.468 \\
.467\end{array}$ & $\begin{array}{l}.469 \\
.463 \\
.440 \\
.422\end{array}$ & $\begin{array}{l}.121 \\
.385 \\
.244 \\
.194\end{array}$ & $\begin{array}{l}.228 \\
.201 \\
.129 \\
.111\end{array}$ & $\begin{array}{l}.098 \\
.099 \\
.084 \\
.078\end{array}$ & $\begin{array}{l}.056 \\
.057 \\
.056 \\
.055\end{array}$ \\
\hline
\end{tabular}

* indicates standard value. 
TABLE 5c

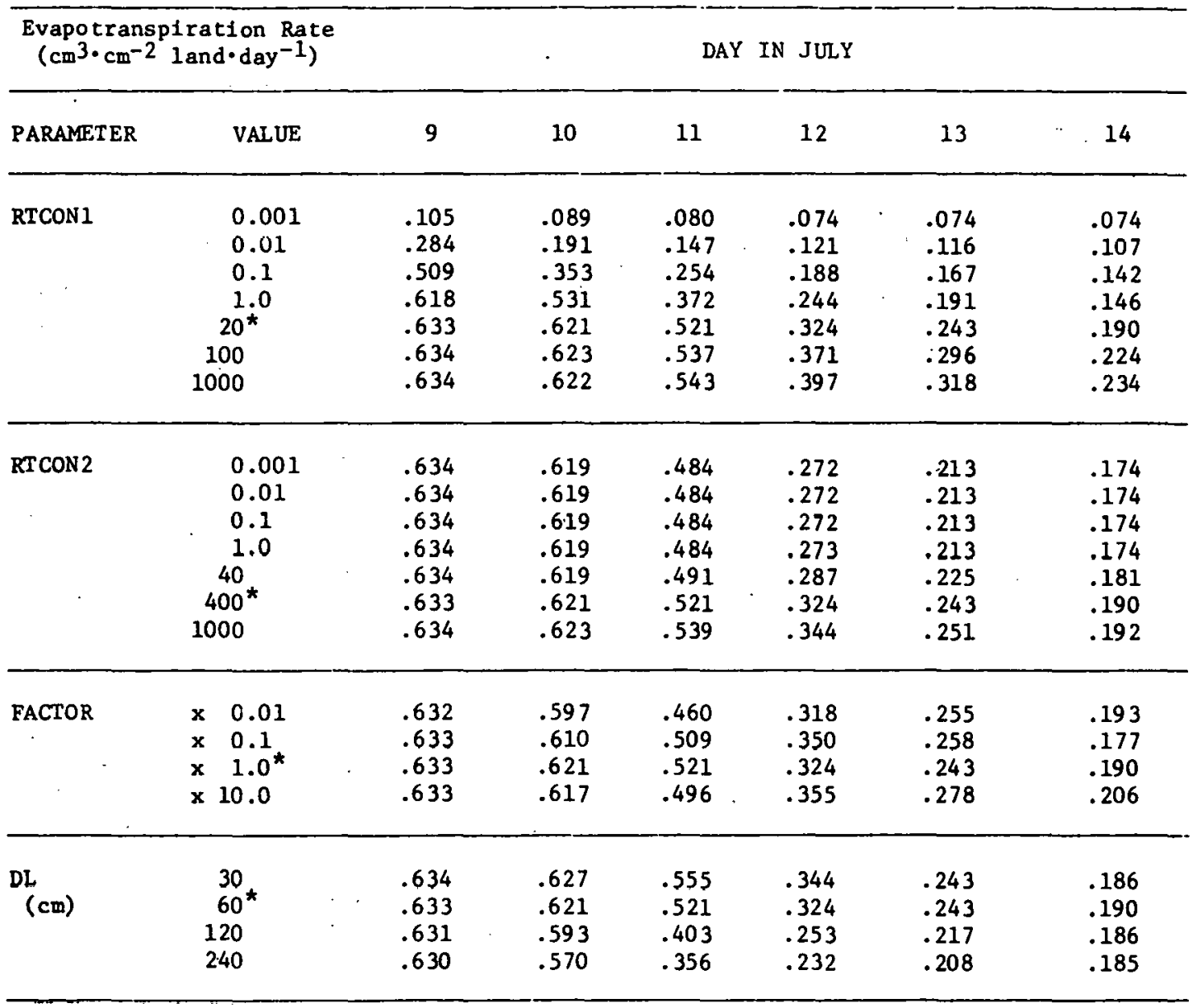

* Indicates standard value: 
TABLE 5d

\begin{tabular}{|c|c|c|c|c|c|c|c|}
\hline \multicolumn{4}{|c|}{$\begin{array}{c}\text { Dralnage Rate } \\
\left(\mathrm{cm}^{3} \cdot \mathrm{cm}^{-2} \text { land } \cdot \text { day }^{-1}\right)\end{array}$} & \multicolumn{3}{|c|}{ DAY IN JULY } & \multirow[b]{2}{*}{14} \\
\hline PARAMETER & VALUE & 9 & 10 & 11 & 12 & 13 & \\
\hline RTCON1 & $\begin{array}{c}0.001 \\
0.01 \\
0.1 \\
1.0 \\
20^{\star} \\
100 \\
1000\end{array}$ & $\begin{array}{l}.120 \\
.102 \\
.080 \\
.058 \\
.029 \\
.017 \\
.013\end{array}$ & $\begin{array}{l}.157 \\
.119 \\
.082 \\
.057 \\
.028 \\
.017 \\
.013\end{array}$ & $\begin{array}{l}.192 \\
.138 \\
.086 \\
.057 \\
.027 \\
.017 \\
.013\end{array}$ & $\begin{array}{l}.209 \\
.148 \\
.090 \\
.057 \\
.027 \\
.016 \\
.013\end{array}$ & $\begin{array}{l}.211 \\
.152 \\
.092 \\
.058 \\
.026 \\
.016 \\
.013\end{array}$ & $\begin{array}{l}.204 \\
.149 \\
.092 \\
.058 \\
.026 \\
.016 \\
.012\end{array}$ \\
\hline RT CON2 & $\begin{array}{c}0.001 \\
0.01 \\
0.1 \\
1.0 \\
40 \\
400^{*} \\
1000\end{array}$ & $\begin{array}{l}.037 \\
.037 \\
.037 \\
.037 \\
.034 \\
.029 \\
.026\end{array}$ & $\begin{array}{l}.036 \\
.036 \\
.036 \\
.036 \\
.033 \\
.028 \\
.025\end{array}$ & $\begin{array}{l}.035 \\
.035 \\
.035 \\
.035 \\
.033 \\
.027 \\
.025\end{array}$ & $\begin{array}{l}.034 \\
.034 \\
.034 \\
.034 \\
.032 \\
.027 \\
.024\end{array}$ & $\begin{array}{l}.034 \\
.034 \\
.034 \\
.034 \\
.032 \\
.026 \\
.024\end{array}$ & $\begin{array}{l}.033 \\
.033 \\
.033 \\
.033 \\
.031 \\
.026 \\
.023\end{array}$ \\
\hline FACTOR & $\begin{array}{cc}\text { x } & 0.01 \\
\text { x } & 0.1 \\
\text { x } & 1.0^{\star} \\
\text { x } & 10.0\end{array}$ & $\begin{array}{l}.000 \\
.006 \\
.029 \\
.011\end{array}$ & $\begin{array}{l}.000 \\
.006 \\
.028 \\
.011\end{array}$ & $\begin{array}{l}.000 \\
.006 \\
.027 \\
.011\end{array}$ & $\begin{array}{l}.000 \\
.006 \\
.027 \\
.012\end{array}$ & $\begin{array}{l}.000 \\
.006 \\
.026 \\
.013\end{array}$ & $\begin{array}{l}.000 \\
.006 \\
.026 \\
.013\end{array}$ \\
\hline $\mathrm{DI}$ & $\begin{array}{c}30 \\
60^{\star} \\
120 \\
240\end{array}$ & $\begin{array}{l}.012 \\
.029 \\
.029 \\
.032\end{array}$ & $\begin{array}{l}.012 \\
.028 \\
.029 \\
.032\end{array}$ & $\begin{array}{l}.013 \\
.027 \\
.029 \\
.032\end{array}$ & $\begin{array}{l}.014 \\
.027 \\
.029 \\
.032\end{array}$ & $\begin{array}{l}.014 \\
.026 \\
.029 \\
.032\end{array}$ & $\begin{array}{l}.014 \\
.026 \\
.029 \\
.032\end{array}$ \\
\hline
\end{tabular}

* Indicates standard value. 
FACTOR value caused the soil drainage to respond very quickly to storm events thus reducing the drainage rate soon after the precipitation. Change in thickness of the soil layers (DL) below the first layer had almost no effects on the surface water relations. There was almost no effect on evapotranspiration rate, however there was an increase in drainage rate with increase in soil layer thickness. Nevertheless there was only a small difference between the drainage from the $60 \mathrm{~cm}$ and $240 \mathrm{~cm}$ layers.

\section{DISCUSSION}

The PROSPER model of the soil-plant system has negative feedback control mechanisms so that a period of high water loss induces a decrease in water supply and reduces the subsequent rates of water loss even though there may be high evaporative demand. Both stomatal closure in plants under water stress and the large decrease in soil hydraulic conductivity with decrease in soil water content provide two important negative feedback controls. The Prosper model has self-correcting properties that are introduced by these negative feedback controls and these are apparent in the tabulated sensitivity data of surtace water relations and daily evapotranspiration rates. The daily drainage rates presented for the six sunny day drying period of ten showed increases with time, however if the data were compared for a longer period the negative feedback due to soil hydraulic properties would become apparent. The drainage responses to the July 8 th rainfall are due to the buffering capacity of the $2.7 \mathrm{~m}$ of soil above the drainage depth. In the longer term, the water balance differences between parameter values tend to be 
reduced. An examination of the overall results reported here suggest that the parameters fall into four subjective types based on the sensitivity of the July water balance components and the shorter term water relations of the vegetation and soil. These four types and associated parameters are

I Mode1 sensitive in both short and long term (in approximate order of decreasing sensitivity). ALMAX, PWPS, RECON1, RLIT, TMS, RSTEM, AT(1), ALBS, ARAT

II Mode1 sensitive on short term but less sensitive in long term (in approximate order of decreasing sensitivity). POWS, RESS, AZIM, INCL

III Model insensitive in short term but sensitive in long term EPXMAX

IV Model insensitive overall (or slightly sensitive) SDRAG, AT(2), RTCON2, FACTOR, DL

The subjective* basis for these four types (Table 6) was visual examination of the data in Figures $1-18$ and Tables 2-5 and this was sufficient to develop some discussion of parameter sensitivity. Application of the PROSPER model requires that the parameters in class I be known with accuracy. (These parameters are subject to the "garbage in, garbage out" phenomenon!) Data on leaf area index (ALMAX), minimum stomatal resistance (TMS) and the leaf water potential at which stomatal resistance becomes maximum (PWPS) are becoming increasingly available

\footnotetext{
*A subjective classification was used so that the project could be completed. A more objective statistical analysis could be made from the data in the tables and figures.
} 
Table 6. Subjective arrangement of parameters into four types based on the sensitivity of the monthly water balance, midday plant water status and daily evapotransplration and drainage rate to change in parameter value.

\begin{tabular}{|c|c|c|c|c|c|c|}
\hline \multirow{2}{*}{$\begin{array}{c}\text { Subjective } \\
\text { Type }\end{array}$} & \multirow[b]{2}{*}{ Parameter } & \multirow{2}{*}{$\begin{array}{l}\text { Monthly } \\
\text { Water Balance }\end{array}$} & \multicolumn{2}{|l|}{ Daily Rate } & \multicolumn{2}{|l|}{$\begin{array}{r}\text { Midday } \\
\end{array}$} \\
\hline & & & Evapotranspiration & Drainage & Water Potential & Conductance \\
\hline \multirow[t]{9}{*}{ I } & ALMAX & 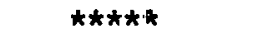 & 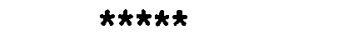 & 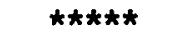 & 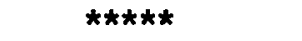 & 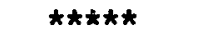 \\
\hline & PWPS & 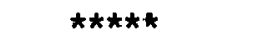 & $\star \star \star \star$ & 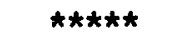 & 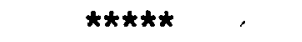 & $\star \star \star \star *$ \\
\hline & RTCON1 & 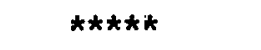 & $\star \star \star$ & 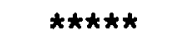 & $\star \star \star$ & $\star \star \star \star$ \\
\hline & RLIT & 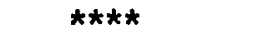 & * & * & $\star \star \star \star$ & * \\
\hline & TMS & $\star * \star$ & $\star \star \star \star \star *$ & $\star \star \star \star$ & $\star \star \star \star$ & 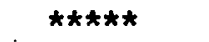 \\
\hline & RSTEM & $\star \star \star *$ & 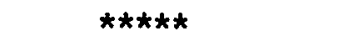 & $\star \star \star \star$. & $\star \star \star \star$ & $\star \star * * * *$ \\
\hline & $\operatorname{AT}(1)$ & $\star \star \star$ & ** & $\star \star \star \star$ & ** & * \\
\hline & ALBS & $\star \star$ & $\star \star \star$ & $\star *$ & $\star \star$ & * \\
\hline & ARAT & $\star$ & $\star$ & $\star \star$ & $\star$ & * \\
\hline \multirow[t]{4}{*}{ II } & POWS & * & $\star \star$ & $\star$ & $\star \star$ & $\star \star \star *$ \\
\hline & INCL & * & $\star \star$ & $\star *$ & $\star \star$ & $\star \star \star *$ \\
\hline & AZIM & * & $\star \star$ & $\star \star$ & $\star$ & $\star \star$ \\
\hline & RESS & * & $\star \star$ & $\star \star$ & $\star \star$ & $\star$ \\
\hline III & EPXMAX & 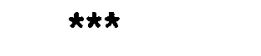 & * & $\star$ & 0 & 0 \\
\hline \multirow[t]{5}{*}{ IV } & SDRAG & 0 & * & 0 & 0 & $\star$ \\
\hline & $\mathrm{DL}$ & $\star$ & 0 & $\star \star$ & $\star$ & $\star$ \\
\hline & RTCON2 & $\star$ & 0 & $\star$ & 0 & 0 \\
\hline & FACTOR & * & 0 & $\star \star$ & 0 & 0 \\
\hline & $\operatorname{AT}(2)$ & 0 & 0 & $\star$ & 0 & 0 \\
\hline
\end{tabular}

[5* highly sensitive $\rightarrow$ * low sensitivity; 0 almost no sensitivity] 
in field studies of soil-plant vater relations (Ritchie and Hinckley 1975; Federer 1976). The root conductivity and stem resistance terms (RTCON1, RSTEM) are less likely to be well characterized. Newman (1972) has highlighted the importance of root resistance (reciprocal of conductivity) as one of the main resistances to water flow in the soilplant system. There is need to modify the PROSPER model structure to include more recent information on this root resistance to water flow. Several studies have shown non-Darcy water flow in plants with the root resistance decreasing with increase in transpiration rate (Newman 1972). The model gives the opposite response of an increase in root resistance with increase in transpiration rate (i.e., soil drying out). Water conduction in the xylem seems to be dependent on the hydrostatic pressure gradient and some estimates of the stem resistance have been made for several species (Peel 1965, Newman 1972). The litter resistance (RLIT) is usually adjusted in model applications such that the value of annual or seasonal soll evaporation is intuitively reasonahle. Original1y RLIT was not included in the daily model reported by Goldstein and Mankin (1972), nevertheless the evapotranspiration rates were reasonable. This is shown in Figure 11 where the sum of soil evaporation and transpiration is almost independent of the value of RLIT. The root density factor (AT(1)) for the first soil layer and the proportional distribution of roots between two root zone layers (ARAT) can influence the model results although ARAT has a minor influence in this study. A few data may be useful for deriving suitable estimates of PROSPER root parameters. Other applications with the model have suggested that the code needs 
deeper root representation to more adequately describe field soil-plant systems (Luxmoore et a1. 1976a, Luxmoore et al. 1976b). Cowan's model of water flow in the soil-plant system (Cowan 1965) has shown that low root densities are capable of supplying transpiration demand. There are interaction effects between RTCON1 and RTCON2 and AT(1) and AT(2) in PROSPER that have not been: investigated here. This study shows results that are dominated by values of RTCON1 and AT(1). Lower standard values for these parameters would increase the model sensitivity to RTCON2 and AT(2). The albedo of vegetation is fairly well characterized for a range of types (Geiger 1957) and normally a value between 0.15 and 0.22 would be suitable for vegetation. The model does not account for changes in albedo during the day. Vegetation has a high reflectivity (high albedo) at low sun angles but since the insolation is small at this time, the model slightly overestimates the radiation reaching the canopy.

The parameters of type II exhibit the negative feedback characteristic whereby short term responses to change in parameter value dampen long term responses. Two leaf characteristics (POWS, RESS) and two slope characteristics (AZIM, INCL) of this sensitivity type can of ten be readily obtained or estimated. If the estimates are poor the simulation results will be more accurate in the long term than the short term.

The maximum interception storage (EPXMAX) can show short term. effects on midday water relations during rainfall, however in the sunny periods there are only minor effects on water relations. The long term 
effect of EPXMAX shows up in the actual interception evaporation. Values of EPXMAX are usually chosen such that the seasonal interception evaporation matches measurement or empirical functions (e.g., Helvey and Patrick 1965).

The parameters of type IV are the soil depth (DL) and hydraulic conductivity characteristics, the canopy wind drag coefficient and two root properties of the second soil layer (RTCON2, AT(2)). The model does not require accurate estimates of wind speed since wind has very iittle influence on the simulation results. The low sensitivity of the model to soil properties is informative and deceptive. The soil hydraulic properties determine drainage rates and simulation of processes in which drainage rates are important (e.g., short term water balance, solute movement) require accurate input values of soil hydraulic properties. The soil system has been greatly simplified in PROSPER. The soil layers are usually 30 to $60 \mathrm{~cm}$ thick in model applications and the soil water is considered to be uniform through each of these layers. Hysteresis in wetting and drying of soil is well known (S1atyer 1967) but has not been included in PROSPER. Omission of hysteresis probably reduces the accuracy of PROSPER forecasts of short term (hourly-daily) soil water status, however, negative feedback increases the accuracy of larger term (daily-weekly) water status estimates.

These sensitivity analyses have relevance to field studies of soil-plant water relations and suggest that estimation of the root and stem resistance to water flow are important in the characterization of short and long term water relations. Reciprocally, field studies have 
shown that vegetation is elastic and undergoes shrink-swell changes during a daily cycle (Kozlowski 1968). This is not included in PROSPER. Building this water capacity aspect into the model may not increase our understanding of water relations per se, however the.coupling of other plant process models (e.g., growth, solute uptake) with PROSPER may reveal important diurnal interactions of plant processes if shrinkswe11 properties were included for the vegetation.

Sensitivity analyses provide a useful reference when new applications are being undertaken. These tests have provided a basis for confidence in the model's utility to a diverse range of applications. The stability and reliable performance of the model over a wide range of parameter values suggests that the model applications could be attempted for most forest or agricultural systems on many soil types in diverse landscape situations. 
REFERENCES

Atmospheric Turbulence and Diffusion Laboratory. 1972. Daily, monthly and annual climatological data for Oak Ridge, Tennessee, Townsite and area stations. January 1951 through December 1971. ATDL Contribution File No. 61. ATDL, Oak Ridge, Tennessee.

Cowan, I. R. 1965. Transport of water in the soil-plant-atmosphere system. J. App1. Ecol. 2: 221-239.

Ecological Sciences Division Annual Progress Report 1971. ORNL-4759. Oak Ridge National Laboratory, Oak Ridge, Tennessee.

Federer, C. A. 1976. Stomatal resistance and stressed potential differ among broadleaved, trees and shrubs. Forest Science (submitted).

Geiger, R. 1965. The climate near the ground. Harvard Univ. Press, Massachusetts.

Goldstein, R. A. and J. B. Mankin. 1972. PROSPER: A model of atmosphere-soil-plant water flow, pp. 1176-1181. In: Proceedings of 1972 Summer Computer Simulation Conference, ACM, IEEE, SHARE, SCI. San Diego, California.

Goldstein, R. A., J. B. Mankin and R. J. Luxmoore. 1974. Documentation of Prosper. A model of atmosphere-soil-plant water flow. EDFB-IBP73-9. Oak Ridge National Laboratory. Oak Ridge, TN 37830.

Greell, R. E. and J. C. Corey. 1971. Salculation of hydraulic conductivity: A furlher evaluation of some predictive methods. Soil Sci. Soc. Amer. Proc. 35: 3-8.

Helvey, J. D. and J. H. Patrick. 1965. Canopy and litter interception of rainfall by hardwoods of eastern United States. Water Resources Res. 1: 193-206.

Huff, D. D., R. 'J. Luxmoore, J. B. Mankin, and C. L. Begovich. 1976. TEHM. Terrestrial ecosystem hydrology model. Oak Ridge National Laboratory, ORNL/NSF/EATC-27, Oak Ridge, Tennessee.

Kozlowski, T. T. 1968. (Ed.). Water Deficits and Plant Growth. Vols. I, II and III. Academic Press, New York.

Luxmoore, R. J. 1973. Application of the Green and Core method for computing hydraulic conductivity in hydrologic modeling. EDFB-IBP73-4. Oak Ridge National Laboratory, Oak Ridge, Tennessee. 
Luxmoore, R. J., D. J. van Rooyen, F. D. Hole, J. B. Mankin and R. A. Goldstein. 1976a. Field water balance and simulated water relations of prairie and oak-hickory vegetation on deciduous forest soils (Soil Science, in press).

Luxmoore, R. J., D. D. Huff, R. K. McConathy and B. E. Dinger. 1976b. Understanding soil-plant water relations of Liriodendron tulipifera (tulip poplar) with the aid of computer simulation (submitted to J. App1. Ecology).

Newman, E. I. 1972. Root and soil water relations. In: E. W. Carson (ed.). The Plant Root and its Environment. pp. 363-440. University Press of Virginia, Charlottesville.

Peel, A. J. 1965. On the conductivity of the xylem in trees. Annals of Botany N.S. 29: 119-130.

Peters, L. N., D. F. Grigal, J. W. Surlin and W. J. Selvidge. 1970. Walker Branch Watershed Project: Chemical, physical and morphological properties of the soils of Walker. Branch Watershed. ORNLTM-2968, Oak Ridge National Laboratory. Oak Ridge, Tennessee.

Ritchie, G. A. and T. M. Hinckley. 1975. The pressure chamber as an instrument for ecological research. In: A. Macfadyen (ed.). Advances in Ecological Research 9: 166-254.

Slatyer, R. 0. 1967. Plant-water relationships. Academic Press, New York.

Swift, L. W., W. T. Swank, J. B. Mankin, R. J. Luxmoore and R. A. Goldstein. 1975. Simulation of evapotranspiration and drainage from mature and clear cut deciduous forests and young pine plantation. Water Resources Research 11: 667-673. 
THIS PAGE

\section{WAS INTENTIONALLY LEFT BLANK}


APPENDIX

Input data set used for the standard sensitivity simulation. The format is described in the documentation of the Terrestrial Ecosystem Hydrology Model (Huff et a1. 1976). 
THIS PAGE

\section{WAS INTENTIONALLY LEFT BLANK}


BATCH

MALKER BRANCH WATERSH?D

1

PRECIPIT ATION-DEPOSITION INPUT

OPEN RAINGAGE INFO

1 I NALKER BRANCH WATERSHED

$$
1
$$
I

INPOT RAINGAGE INFORMATION $\$$ 19999 PORK
THIS IS THE JULY VERSION 25

11

\author{
(CALL PRECIP)
}

(CALL OPNSET)

(CALL NEUSTA)

$10903558.00 \cdots \mathrm{N} 84 \quad 17 \cdot 00 \cdot$ HRECORDING

READ HOURLY PRECIPITATTON

Y ES

0006

0006

0006

0006

0006

0006

0006

0006

0006

0006

0006

0006

0006

0006

0006

0006

0006

0006

0006

0006

0006

0006

0006

0006

0006

0006

0006

0006

0006

0006

0006

0006

0006

0006

0006

0006

0006

0006

$\$$

$\$$

SEAD HONTHLY DEPOSITTON

Y ES

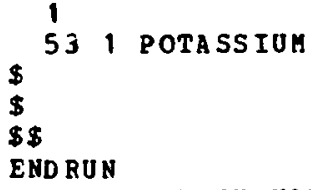

END RUN

HALKER BRANCH WATERSHED

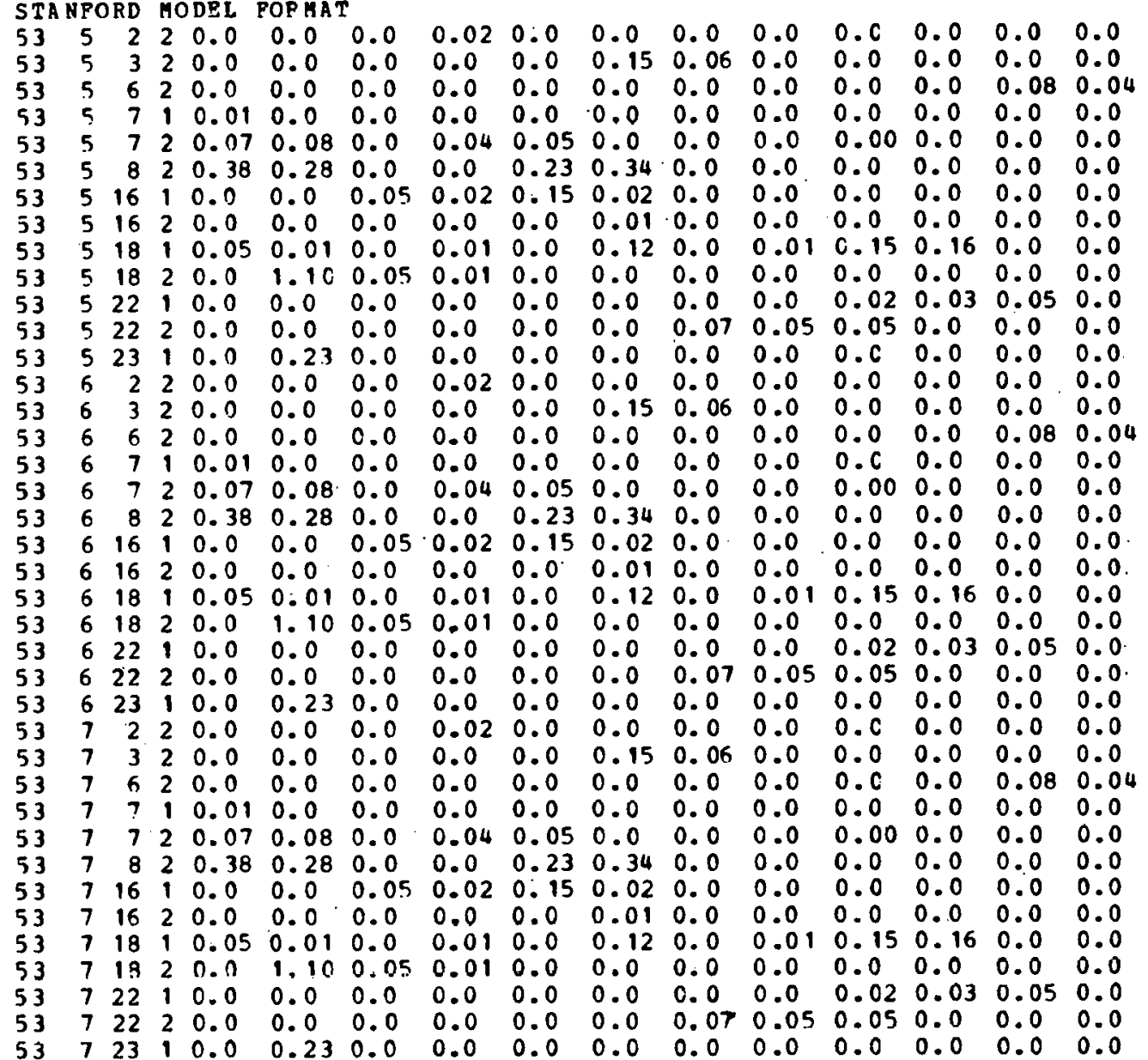

(CALL MCDEPS) 


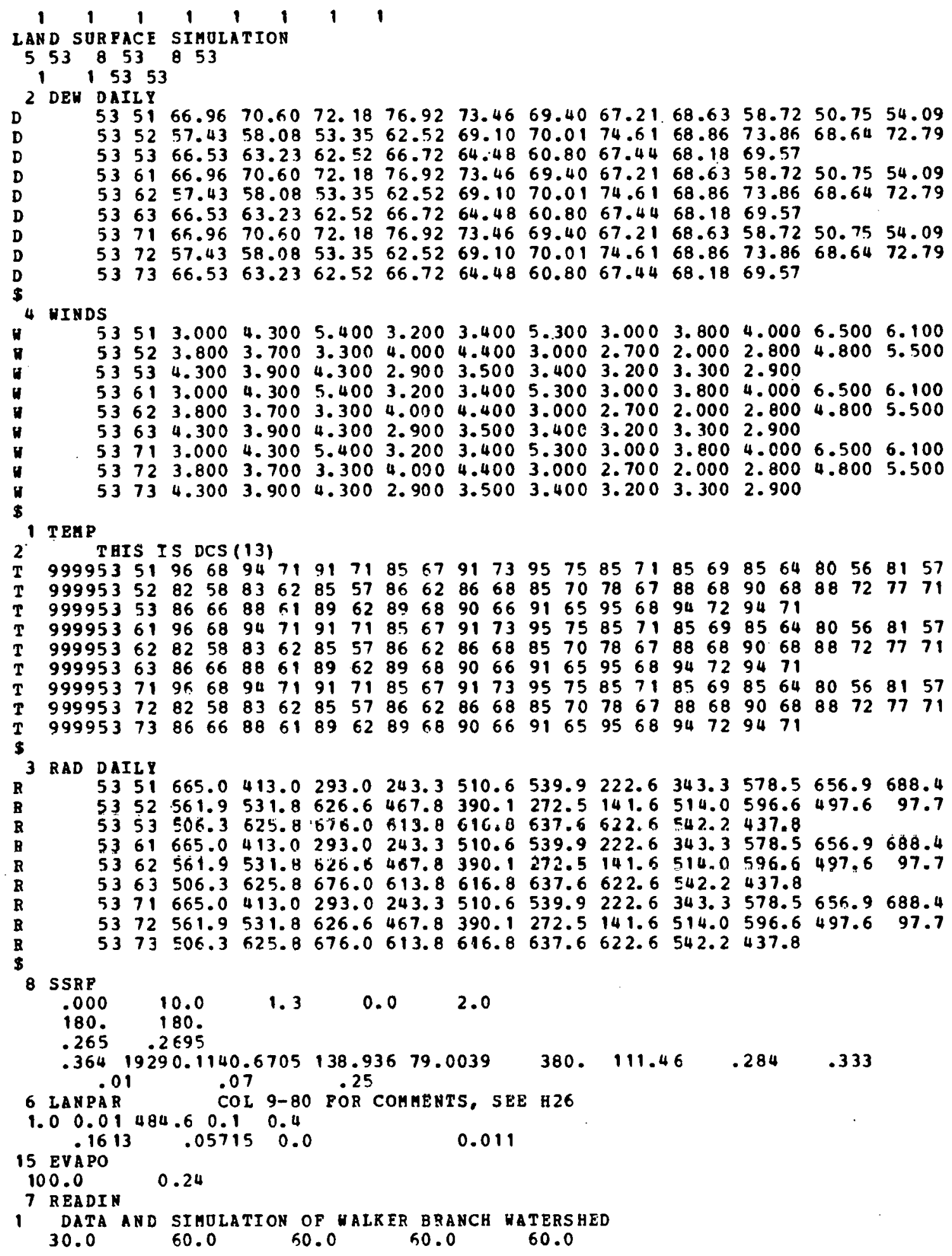




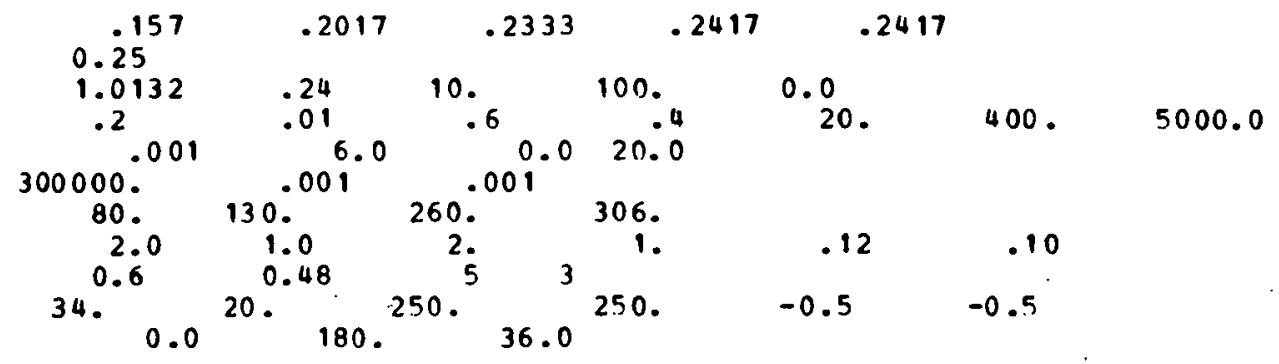

$\begin{array}{clcll}\text { PULLERTON } & \text { A } 2 / S & \text { WALKER } & & \\ 9 & 50 & .27 & 21.8 & 0.0 \\ 73.49 & 0.999 & .01138 & 15 . & 980 .\end{array}$

2.0

.125 .143 .159 .170 .187 .210 .240 .263 .270

15000.5000. 1000. 667. 333. 100 . PULLERTON B21/S WALRER BRANCH

$\begin{array}{cllll}9 & 50 & .246 & 10.9 & 0.0 \\ 73.49 & 0.999 & .01138 & 15 . & 980 .\end{array}$

2.0

.166 .177 .187 .193 .201 .211 .225 .236 .246

15000.5000 .1000 .667 .333 .600$.

PULLERTON B22I/S WALKER BRANCH

$\begin{array}{ccccc}9 & 50 & .304 & 10.9 & 0.0\end{array}$

$\begin{array}{lllll}73.49 & 0.999 & .01138 & 15 . & 980 .\end{array}$

2.0

.184 .198 .211 .218 .226 .257 .278 .298 .304

15000. 5000. 1000. 667. 333. 100 .

INPIITRATION CURVE/S FOPEST SOIL

15. $0.0 \quad 0.0 \quad 21$

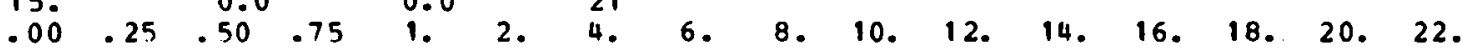

24.26 .28 .30 .60 .

$.00 \quad .15 \quad .83 \quad 1.75 \quad 2.74 \quad 6.8215 .0023 .2931 .5739 .8648 .1556 .4464 .7273 .0181 .3089 .59$ 97.87106 .2114 .4122 .7247 .0

$16 \mathrm{GO}$

END RUUN 
ORNL/TM-5343

UC-11

\section{INTERNAL DISTRIBUTION}

1-8. S. I. Auerbach

9. C. L. Begovich

10. A. A. Brooks

11. R. L. Burgess

12. R. C. Dahlman

13. K. R. Dixon

14. J. O. Duguid, Jr.

15. D. E. Fields

16. C. W. Francis

17. W. Fulkerson

18. R. H. Gardner

19. F. G. Goff

20. T. Grizzard

21. W. F. Harris

22. G. S. Henderson

23-24. J. T. Holdeman

25. F. O. Hoffman

26. D. D. Huff

27. D. R. Jackson

28. S. V. Kaye

29. G. G. Killough

30. S. E. Lindberg

31-42. R. J. Luxmoore

43. J. B. Mankin

44. S. B. McLaugh 1in
45. R. D. McCulloch

46. R. K. McConathy

47. R. E. Moore

48. B. D. Murphy

49. J. S. O1son

50. R. V. O'Neill

51. D. C. Parzyck

52. M. R. Patterson

53. H. Postma

54. M. Reeves

55: D. E. Reichle

56. C: R. Richmond

57. P. S. Rohwer

58. D. S. Shriner

59. H. H. Shugart, Jr.

60. E. G. Struxness

61. D. E. Todd

62. R. R. Turner

63. R. I. Van Hook

64. Biology Library

65-66. Central Research Library

67-68. Laboratory Records Dept.

69. Laboratory Records, ORNL-RC

70. ORNL Patent Office

71. ORNL Y-12 Technical Library

\section{EXTERNAL DISTRIBUTION}

72. Research and Technical Support Division, ERDA-ORO

73. R. P. Betson, Hydrologi.c Research and Analysis Staff, TVA, 331 Evans Building, Knoxville, I' 37902

74. J. C. Corey, E. I. Dupont de Nemours, Savannah River Laboratory, Aiken, SC 29801

75. N. H. Crawford, Hydrocomp, 1502 Page Mill Road, Palo Alto, CA 94304

76. J. M. Davidson, Soil Science Department, University of Florida, Gainesville, FL 32611

77. Paul B. Dunaway, Office of Effect Evaluation, USERDA, Nevada Operations nffice, P.O. Box 1400, Las Vegas, NV 89114

78. P. M. Fleming, Division of Land Use Research, CSIRO, P.0. Box 109, Canberra City, ACT 2601, Australia

79. R. Franklin, Division of Biomedical and Environmental Research, ERDA, Washington, DC 20545

80. S. P. Gessel, School of Forestry, University of Washington, AR-10, Seattle, WA 98195 
81. R. A. Goldstein, Electric Power Research Institute, Palo Al to, CA 94303

82. D. F. Grigal, Associate Professor, Department of Soil Sciences, The University of Minnesota, St. Paul, MN 55101

83. Douglas A. James, Division of Biomedical and Environmental Research, ERDA, Washington, DC 20545

84. Dale W. Johnson, College of Forest Resources, University of Washington, AR-10, Seattle, WA 98195

85. Ulrik Lohm, Swedish Coniferous Forest Project Base 7008, S-75007, Uppsala, Sweden

86. Dr. Frank McCormick, Director, Institute of Ecology, University of Tennessee, 408 10th Street, Knoxville, TV 37916

87. C. E. Murphy, E. I. Dupont de Nemours, Savannah River Laboratory, Aiken, SC 29801

88. W. S. Osburn, Division of Biomedical and Environmental Research, ERDA, Washington, DC 20545

89. C. L. Osterberg, Division of Biomedical and Environmental Research, ERDA, Washington, DC 20545

90. A. J. Peck, Division of Land Resources Management, CSIRO, Private Bag, P.0. Wembley, Western Australia 6401, Australia

91. D. C. Reicosky, Coastal Plains Soil and Water Conservation Research Center, P.O. Box 3039 - West Florence Station, Florence, SC 29501

92. H. D. Scott, Department of Agronomy, University of Arkansas, Fayetteville, AR 72701

93. R. E. Sojka, Department of Soils, North Dakota State University, Fargo, ND 58102

94. Janice L. Stolzy, c/o Department of Soil Science and Agricultural Engineering, University of California, Riverside, CA 92507

95. L. H. Stolzy, Department of Soil Science and Agricultural Engineering, University of California, Riverside, CA 92507

96. Wayne T. Swank, Coweeta Hydrologic Laboratory, U.S. Forest Service, Franklin, NC 25734

97. L. W. Swift, Loweera Hydruluyic Labuidtory, U: E. Forest Servire, Franklin, NC 25734

98. Jeff Swinebroad, Ecological Sciences Branch, Division of Biomedical. and Environmental Research, ERDA, Washington, DC 20545

99. R. Watters, Division of Biomedical and Environmental Research, ERDA, Washington, DC 20545

100. Dr. Frank W. Woods, Forestry Department, 248 Plant Sciences Building, University of Tennessee, Knoxville, TV 37916

101-282. Given distribution as shown in TID-4500 under category UC-11 Environmental Control Technology and Earth Sciences 